Article

\title{
The Catholic Bishops in the U.S. Public Arena: Changing Prospects under Pope Francis
}

\author{
Richard L. Wood \\ Department of Sociology, University of New Mexico, MSC 05 3080, Albuquerque, NM 87131-0001, USA; \\ rlwood@unm.edu \\ Academic Editor: Timothy A. Byrnes \\ Received: 9 November 2015; Accepted: 18 January 2016; Published: 4 February 2016
}

\begin{abstract}
The public profile of the Roman Catholic bishops of the United States results not simply from their own interventions in political life, but from the broad array of actions and actors within "public Catholicism" broadly conceived. This article assesses the contemporary profile of the American bishops from this broad angle, particularly in light of new dynamics under the papacy of Francis I. It does so by documenting public Catholicism's presence in ecclesial institutions, other public institutions, and lay-centered social movements (particularly faith-based community organizing) and via a case study of the healthcare reform debate around the State Children's Health Insurance Program and the Affordable Care Act. Cultural and institutional factors shaping Catholic public presence are analyzed in three dimensions of social life: institutional leadership; authority dynamics within the Church; and the culture of prayer, spirituality, and worship in parishes. Finally, the conclusion discusses the key dynamics likely to shape the future of public Catholicism in America.
\end{abstract}

Keywords: Roman Catholic bishops; United States Conference of Catholic Bishops; public religion; public Catholicism; health reform; Affordable Care Act; faith-based community organizing; PICO National Network

\section{Introduction}

This article analyzes the public profile of Roman Catholic bishops of the United States, with a particular eye toward how that profile is changing under the dynamic conditions created by the governance of Pope Francis. However, the public profile of the American bishops emerges not just from their own public interventions, but much more fundamentally from the broader institutional profile of the Catholic Church in America which they lead. Therefore, before projecting what current dynamics may portend for the future, the article first pays attention to the structural conditions resulting from recent decades of American Catholic public life-both the high-level national picture within church and society, and more diffuse dynamics within broad segments of the Catholic community and American society as a whole. That is, I consider "public Catholicism" broadly conceived as well as the more specific profile of the American bishops.

If considered as a static picture, this analysis would suggest two key insights: first, institutionally public Catholicism has built and maintained an impressive presence at all levels of church and society, which positions it to exert significant influence on American public life, in ways I will argue are entirely appropriate in a democratic public sphere. Second-and in analytic tension with the first insight-specific cultural dynamics within the Church have systematically undermined the wider impact of public Catholicism. However, that static picture obscures more dynamic changes underway: Pope Francis is having his most significant impact on the Catholic social imagination and thus the cultural dynamics within the Church. As a result, public Catholicism may be entering a new moment of potential influence-if the bishops and other sectors of American Catholicism can successfully overcome the cultural dynamics that have thus far undermined their influence. Thus, this article offers 
a reflective essay on the contemporary conditions and future promise of public Catholicism under the leadership of the current American bishops. I hope to offer insight, if not into the American Catholic future itself, at least into the key dynamics that will give birth to that future.

Anyone hopeful for democracy in the United States-Catholic or otherwise-might well be troubled by the state of American public Catholicism today. Catholicism has certainly not lost its public voice. Catholicism's historically fruitful dialogue with American culture-carried on in diverse ways by leaders both lay and clerical, from Bishop John Carroll and Orestes Brownson in the 18th and 19th centuries to John Ryan, Dorothy Day, George Higgins, Jack Egan, Thomas Merton, and Cardinal Joseph Bernardin in the 20th century-in some ways continues today [1]. However, amidst the linked sexual abuse and authority scandals in the Church, and acute political polarization in the wider society, leaders in both church and society seem increasingly tone-deaf to the appropriate give-and-take of public dialogue in a democratic society. This chapter argues that, if Francis and the bishops can vigorously re-launch that historic dialogue, the Church's social teaching and institutional presence hold vast potential to play a leavening role in American public life. Pope Francis appears to desire this kind of re-launch, but with an important new twist analyzed below. I argue that if American Catholic leaders resist such a re-launch, the Church risks sacrificing its historical role as an important public interlocutor in the evolution of American society, in the name of a more sectarian self-understanding that has emerged over the last two decades.

The article first outlines an analytic framework through which to examine the relationship between public Catholicism and American society. Next, I extend José Casanova's influential analysis of "public religion in the modern world" to document Catholicism's public presence as carried in three sectors of American life: ecclesial institutions, from the national bishops' conference and state-level bishops' conferences, to dioceses/archdioceses, Catholic universities and local parishes and schools; other public institutions, ranging from Congress and the Supreme Court to state and local elected officials and non-governmental institutions; and lay-centered social movements [2]. I portray public Catholicism in action through a brief case study of the Catholic involvement in the 2007-2010 healthcare reform debate that led to the Affordable Care Act, otherwise known as Obamacare. The core of the analysis then considers cultural and institutional factors shaping Catholic public presence in three areas: institutional leadership, authority dynamics within the Church, and the culture of prayer, spirituality, and worship in parishes. Finally, the conclusion discusses the key dynamics likely to shape the future of public Catholicism in America.

\section{Thinking about Public Catholicism: An Analytic Framework [3]}

Catholics and non-Catholics alike may be tempted to identify "public Catholicism" with the public voice of the bishops in addressing social policy. Certainly the bishops represent the most crucial dimension of the Church's public witness, but it is a mistake to reduce public Catholicism only to this dimension. It is far better to start with an adequate understanding of the notion of "the public" in order to properly consider what we mean by public Catholicism.

Contemporary democratic theory holds that democracy is not simply the product of elections and representative institutions, but rather is built upon a foundation of societal-wide dialogue through which citizens reflect upon their experience and current situation, and establish priorities and commitments that flow into and shape the political process through those elections and representative institutions [4-13]. Since Vatican II, the Catholic Church has largely embraced this understanding of democratic institutions; certainly Pope Francis appears deeply committed to democratic institutions in national decision-making and to a process of political inclusion whereby all sectors of a national population are part of societal dialogue $[14,15] .^{1}$

1 Note that the discussion of the public sphere here concerns the relationship of the Catholic Church to its wider societal context within the United States, in which a democratic public sphere is the consensual ideal.Of course, in its internal life 
Democratic deliberation thus occurs at multiple levels: among citizens, between leaders of all kinds of institutions, and among political leaders. All such sites constitute what democratic theorists call the "public sphere". Although this democratic ideal posits that all members of a society participate in the public arena on equal footing, in reality differing levels of power mean some people shape public dynamics more than others-and some people may be illegitimately excluded due to lack of cultural or economic resources, or due to gender, race, sexual orientation, etc. Egalitarian themes within Catholic social teaching become especially relevant here, due to that tradition's emphasis on judging societal arrangements partly through the lens of their impact on those who were previously marginal in society [16-18].

In this way of understanding the public sphere, "public Catholicism" cannot be narrowed to the role of the Catholic bishops. Doing so would collapse to a few voices what is objectively a far more diverse set of individual voices and institutional channels through which the Catholic tradition shapes American consciousness. Thus, we are dealing with public Catholicism everywhere that the Catholic worldview is brought to bear in deliberations within the public sphere undergirding American democracy. In a sense, then, it is the whole Catholic tradition that sustains a dialogue with American culture, with that dialogue carried on at many levels simultaneously, by theologians and Catholic scholars in their intellectual work; by deacons, religious sisters and brothers, and priests in preaching and teaching; by lay Catholic leaders within secular institutions; by Catholic businessmen and politicians within corporations and government. Ultimately, the Catholic understanding of the authoritative office of the bishops means that they are arbiters of the Catholic tradition's stance in this societal-wide dialogue; however, as we shall see, without these other voices that dialogue would be much impoverished. The voice of the bishops thus constitutes the central flow among many that make up the overall current of American public Catholicism, with other important channels, cross-currents, and subterranean flows also important to the overall picture. This portrayal emphasizes the actual ways that Catholicism relates to American culture, and is also consistent with democratic political norms, in which social policy is driven by effective argumentation and political discernment, not via a privileged Church voice directly shaping political life.

In utilizing this model of church-society relations within the public sphere, we must remember that there are two different modes of authority at work in the two settings. Within the Church, authority is ultimately hierarchical in structure. It is "top-down", although not absolutist in that when internal church dynamics are healthy, multiple currents of Catholic teaching are in play within that hierarchically structured authority; however, it is inherently hierarchical, with the bishops holding an authoritative voice that Catholics are expected to take seriously as they make decisions on public matters. In contrast, within the wider society authority is democratically structured through participative and representative institutions, often colloquially described as "from the bottom up." In fact democratic authority is a good deal more complex than that phrase implies, with multiple hierarchical authority structures in play, including scientific authority, authority rooted in corporate and (to a much lesser extent) labor union hierarchies, and the authority attached to icons of popular culture and religious belief. However, the top-down versus bottom-up imagery captures a key distinction between authority within Catholicism, structured by complex authoritative hierarchy, and authority within the democratic public sphere, structured by democratic relations.

Used poorly, such a broad understanding of the public sphere might risk becoming analytically useless by requiring us to pay attention to everything at once. However, here we can avoid this risk: as a relatively coherent spiritual and intellectual tradition that revolves around specific institutional nodes, Catholicism lends itself to a focused analysis limited to a relative handful of such institutions.

the Church itself is not a democracy, neither in ideal nor in practice, but rather an authoritative institution in which the vertical definition of truth holds a prominent position. See discussion below of the interface between internal church life and the external relationship with democratic society. 
Institutions of Public Life: Ecclesial and Secular

We can think of Catholic public influence being exerted through two broad channels. On one hand, Catholic teaching flows down and out to the wider society, originating in papal and episcopal teaching authority and flowing through ecclesial institutions explicitly committed to Catholic worldview and practice. On the other hand, Catholic worldview and social commitments might flow upward through the institutions of society, as a result of the cultural influence of individual Catholics in civil institutions and electoral politics. Figure 1 sketches these complementary potential channels of Catholic influence, as well as an important "middle" route of influence.
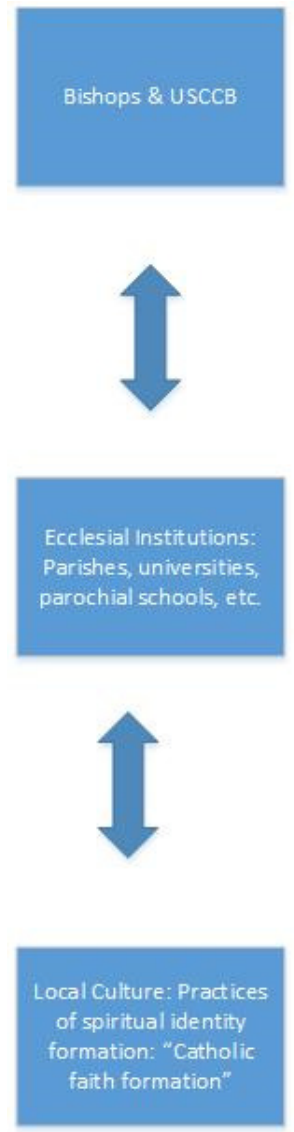
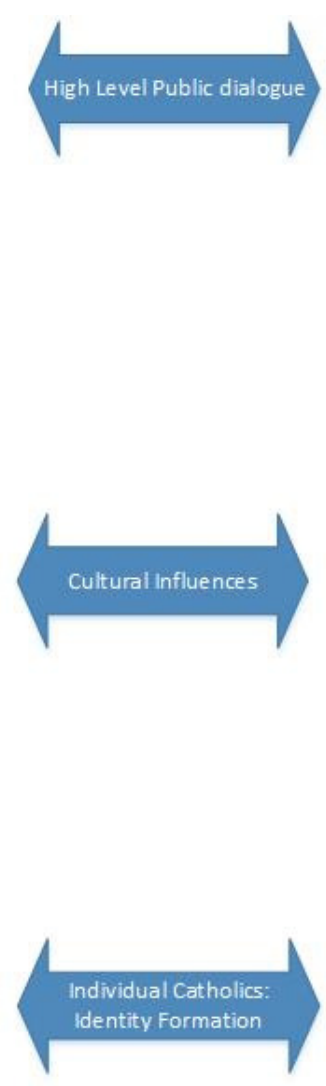
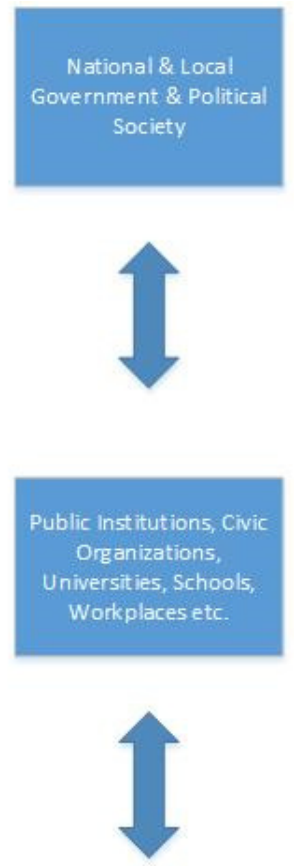

Local Culture: Identity

Formation In American society: Civil Society Practices and "mass culture"

Figure 1. Public Catholicism—channels of influence between church and society.

As depicted in Figure 1, analyzing public Catholicism requires paying attention to a diverse array of institutional settings, from parishes and diocesan organizations to national-level episcopal structures, and from local civil society to the Supreme Court. Neither those analyzing the public role of Catholicism nor the bishops themselves do well to reduce the influence of Catholicism on the voice of the bishops; rather, the Catholic tradition shapes American public life through the variety of channels shown here. Figure 1 assumes a relatively free flow of culture between the ecclesial sector and the wider social world. This is in keeping with the contemporary reality that American Catholics no longer exist in a separate, sectarian subculture within American society, as arguably was the case up through the 1950s. Rather, Catholics have fully joined the broad American cultural and social milieu, with most individual Catholics operating competently within both Catholic settings and the wider culture [19-21].

Although public Catholicism exerts social influence through both elite dialogue and more dispersed cultural flows above the level of the individual, in the long term it will only have significant influence to the extent that the complex and cross-cutting identity-forming pressures 
produce individuals with discernibly "Catholic" identities. For if there is no distinction between being Catholic and being American, then American Catholicism simply dissolves into the wider mainstream culture. This makes understanding what Catholics call "faith formation" crucial to assessing public Catholicism. This is the "identity formation" level shown in Figure 1, and includes the practices of spirituality and worship centered in parishes, as well as the intellectual commitments shaped by theologians and disseminated through Catholic teaching and preaching.

Though some regret the fact that lay Catholics now live fully within both church and society, lamenting it as the death of a distinctively traditional Catholicism, sociologically it reflects American Catholics' successful upward mobility over several generations, and American society's successful dismantling of anti-Catholic nativism. It also represents the opportunity for American Catholicism to effectively shape the wider society: as long as Catholics resided in a subculture of their own, their ability to reshape the wider culture was quite limited. By bridging between broad American cultural patterns and the Catholic worldview carried within parish life, contemporary American Catholics bring Catholicism to bear within the ongoing evolution of American culture, both at the grassroots and at higher institutional levels.

This brings us to the "cultural influence" level shown in Figure 1. Beyond individual identity formation, equally or more important is the way that public Catholicism shapes and is shaped by broader American culture. To think about this, it is helpful to imagine American society not only as a collection of individual Americans, but also as the product of interweaving cultural strands that shape American life [22]. That is, American life is a stream made up of a variety of cultural currents, intermingling in complex ways yet preserving themselves as evolving cultural traditions (including traditions based upon democratic commitments, religion, ethnic and racial identities, mass consumerism, "new age" and artistic humanism, utilitarianism, nationalism, etc.). In this metaphor, public Catholicism is one such cultural current, shaping and being shaped by American culture in ways not reducible to individual identity formation. Rather, public Cholicism also bridges between authoritative teaching internal to the Church and the flow of democratic authority in American society.

From the standpoint of advocates of public Catholicism, this bridging represents an advance, rather than a retreat, if and only if Catholic culture preserves sufficient coherence to play that role. Theologically, such an understanding harmonizes well with Gerhard Lohfink's analysis of the early church as a "contrast society" to the wider culture [23]. Two points are crucial here, which can be best appreciated by extending the "bridging" metaphor: a bridge must be securely anchored at both ends, or it cannot function as a bridge. Thus, at one end, the Church as a contrast to society must coherently articulate and clearly live out its own identity and self-understanding. At the other end, the Church must not only in principle affirm democratic life and freedom of conscience, but also in practice accept the dynamics of democratic authority in political decision-making. That is, from the standpoint of Catholics, "bridging" must be faithful to the Church's self-understanding; simultaneously, from the standpoint of the non-Catholic public, this bridging represents a legitimate voice for public Catholicism if and only if the key actors in public Catholicism accept the rules of the democratic public sphere: viz., that religious leaders (1) enter the public arena to try to convince others that their views will best serve the common good; (2) recognize that pursuit of the common good is a complex political art and a skilled craft, in which specialists (called politicians) pursue partial victories that pave the way for deeper future victories; and (3) enter the public arena open to the possibility of others providing convincing counter-arguments, i.e., that they might revise their views.

Refusal to accept these terms of democratic life, in the name of a purer absolute good, potentially leads to the situation of the Catholic Church behaving as a sect-an oxymoron in traditional Catholic self-understanding, but nevertheless a contemporary alternative, as we shall see.

The notion of the Church as a contrast society is thus different from the notion of a Catholic subculture. In the former, the Catholic community exists in relationship to but some tension with the wider society, and accepts the terms of the "bridging" metaphor discussed here. In the latter, the Catholic community understands itself, and to some degree actually exists, in isolation from the 
wider society-and often as simply resistant to it. Accepting the democratic norms of contemporary public life has been historically difficult for the Catholic tradition to embrace, coming only via the Second Vatican Council and subsequent papal statements - both influenced by the American Catholic experience via the theologian John Courtney Murray [24,25].

Catholics (whether conservative or progressive) who prefer a more prophetic/critical stance towards American culture will surely respond that no prophetic social role is possible if American Catholicism simply embraces the wider culture. I do not argue for a blind embrace of the wider culture. If the Church understands itself as "leaven" for the "dough" of the wider society, it must to a significant degree serve as a contrast to that society- "leavening" presumes a distinction between the leaven and the dough. Thus, the notion of the Church as a contrast society returns us to the theme of identity formation: if church institutions can effectively shape an American Catholic identity that holds its own amidst the pressures of popular culture, then American Catholics are, as demonstrated below, impressively positioned to shape the wider culture in ways not previously possible. However, the point here is that prophetic Catholicism cannot reject all normal political compromise if it wants to play this leavening role.

Thus, the American bishops-and public Catholicism more generally-stand institutionally and culturally on complex terrain. The next two sections begin a concrete analysis of that terrain, by considering the profile of a broad set of church-related institutions and their role in one of the most important recent debates in U.S. politics.

\section{Catholicism's Institutional Presence in American Life}

Catholicism is brought to bear in public life through church-sponsored institutions headed by the bishops, through church-related institutions that the bishops influence less directly, and through the presence of Catholic individuals in autonomous social movements.

In briefly outlining Catholicism's presence in American life, I pay attention both to the raw numerical weight of Catholic institutional and individual presence in these settings, and to the subtler dynamics of Catholic influence within these institutions. I divide the discussion into ecclesial institutions, other public institutions, and lay-centered social movements-recognizing that the level of institutional control by Catholic bishops varies substantially across these levels. Such episcopal control is strongest in official ecclesial institutions directly affiliated with dioceses, weaker in those affiliated with religious orders, and weaker still vis-à-vis public institutions and lay-centered social movements (although episcopal influence in the latter varies greatly). This creates a significant pluralism of Catholic perspectives and directions of influence, despite outside perceptions of a monolithic Catholic voice.

\subsection{Ecclesial Institutions}

In terms of sheer institutional presence, Catholicism maintains an impressive and growing weight in American society. In 2007, there were 19,044 parishes in the United States, spread broadly across the geographic regions, social settings, and-importantly-the districts that elect presidents, congressional representatives, state officials, city council members, and school boards [26]. This represents an increase of 1102 parishes since 1967 (6\% increase), though there has been a decrease of 583 parishes since 2000 (3\% decline), as dioceses strapped for financial resources and ordained clergy have closed some churches.

Far outpacing this slow, four-decade rise in the number of American parishes, the number of Catholics per parish has increased significantly, from 2614 to 3544 members in the average parish ( $36 \%$ increase). This has been driven by a dramatic increase in the total Catholic population, from 46.9 million to 67.5 million ( $44 \%$ increase since 1967), primarily due to immigration. Simultaneously, the number of ordained men who lead most of these parishes has declined $40 \%$, and the number of religious sisters and brothers who once provided crucial additional staffing in parishes, schools and other settings has fallen most precipitously of all (63\%). As a result, the number of Catholics per priest or religious brother/sister has risen by $220 \%$ during this four-decade period [27]. 
From the point of view of cultural sociology, we can assume that where institutional Catholic influence wanes (as reflected roughly by declining numbers of priests and religious sisters/brothers, or thinner institutional life generally), the identify-formation dynamics among lay Catholics will be increasingly influenced by mass American culture. That is, individual identity formation is shaped by both internal Catholic and wider cultural dynamics; where the former is weaker, the latter may hold greater sway.

However, a wide Catholic institutional presence remains within American culture. Beyond parishes, the church's presence includes 557 hospitals assisting some 83 million patients per year, often at times of personal crisis, and often with explicitly Catholic pastoral care offered alongside medical expertise. Their influence is difficult to assess in any rigorous way, but they provide medical attention explicitly rooted in Catholic values and pioneered such innovations as clinical pastoral care that combine medical and spiritual solace. In addition, approximately 1004 day care centers and 2856 specialized social service centers serve a broad constituency of low- and middle-income non-Catholic and Catholic clients. Some 769 parish-affiliated high schools and 583 other Catholic high schools serve approximately 608,000 students (nearly a fifth of who are non-Catholic) during the key identity-shaping teen years; and more than 6500 Catholic schools serve more than 1.6 million elementary school students. Finally, more than 3.8 million elementary and high school aged children are reported to partake in religious education through parishes nationwide. All this adds up to an impressive Catholic institutional presence in American life, albeit one whose cultural influence is difficult to verify and in any event has likely waned significantly in the face of societal changes of recent decades [28].

Meanwhile, the state of American ecclesial finances has deteriorated markedly. As Francis Butler noted in 2006, U.S. dioceses "face an era of rising costs, diminishing reserves and insufficient income...Dioceses appear to be running through their reserves at an alarming rate...The reason for this is simple: it's due to the outflow of grants to sustain parishes operating at a loss" [29,30]. Butler went on to note these deficits are primarily associated with parishes housing parochial schools.

Since that time, these structural deficit problems have been exacerbated by the costs of settlements with victims of clergy sexual abuse: from 2004 to 2008, American dioceses and their equivalents faced costs related to sexual misconduct allegations that varied between $\$ 139$ million and $\$ 498$ million annually. With a total of almost $\$ 1.7$ billion paid out over that period and approximately $60 \%$ paid directly by dioceses ( $40 \%$ paid by insurance), this has been an enormous drain on church finances. In addition, the finances of men's religious communities deteriorated dramatically: \$281 million was paid out to settle sexual abuse cases from 2004 to 2008. These financial liabilities accumulate further since 2008; whether they have now peaked remains unclear, as the financial sums and the numbers of new allegations show no consistent pattern. Incalculable but serious damage to the church's public credibility has also been done by the supervisory malfeasance of some bishops, which exacerbated the sexual abuse scandal. That this negligence partly reflected prevailing practices in the wider culture has not lessened its impact. The resulting authority scandal is beyond my purposes here, but has surely undermined the credibility and legitimacy of the bishops' authoritative voice [31].

More complex has been the financial situation of women's religious communities. Some have prospered financially by selling off medical and other institutions to endow their communities or to promote social justice and charitable endeavors; many others confront profound financial crises as members aged and faced high medical costs and low recruitment of new members.

The resulting ecclesial financial difficulties, combined with the rising influence of some bishops resistant to national episcopal influence in their dioceses, led to an important downsizing of the United States Conference of Catholic Bishops (USCCB) during 2005-2006. The retrenchment instituted a leaner organizational structure and sharp reductions in staffing. While some of this reorganization may have been overdue, it is hard to avoid the conclusion that it also represented a significant scaling back of organizational aspiration and capacity, and a lower priority to some areas of historic episcopal priority: whereas the bishops' most prominent interventions in public discourse in the 1980s involved criticism 
of nuclear weapons policy, economic inequality, and American intervention in Central America, in recent years they have involved criticism of abortion rights, embryonic stem cell research, gay marriage and other forms of domestic partnership legislation. This represents an important shift of public profile, albeit one that should not be exaggerated—after all, throughout these decades the bishops have also continued to speak out on a wide spectrum of social issues, including opposition to the death penalty, concern about poverty in America, and support of immigrants' rights. Nonetheless, a greater emphasis on 'conservative' issues and a more partisan tenor of political messages has been widely perceived, along with a de-emphasis on the integrated "seamless garment" approach advocated by the late Cardinal Joseph Bernardin.

Throughout these shifts, the USCCB has remained the Catholic bishops' primary voice in national public affairs, through such activities as educating and lobbying congressional representatives regarding the bishops' issue priorities; the periodic promulgation of statements such as Faithful Citizenship, intended to inform Catholic political choices during the 2008 elections and since; and the anti-poverty program Catholic Campaign for Human Development, which each year distributes some $\$ 10$ million in funding to empower poor communities.

Other ecclesial institutions have fared far better in recent years. A less-known story involves the continuing work and influence of Catholic lobbying efforts through the "Catholic conferences" sponsored by groups of bishops in some 32 states. David Yamane [32] discusses the influence of these bodies on public policy at the state level, on issues ranging from capital punishment to abortion to anti-poverty policy to education funding; he argues that the bishops' lobbying efforts at this level have been largely unaffected by the recent sex and authority scandals, and remain quite strong (at least as of 2004). Much less certain is the effect of the recent church financial implosion and the broader economic downturn, and whether the state conferences have been able to sustain their funding and activity.

Catholic universities and colleges represent another key facet of the public profile of American Catholicism. While their relative independence has been objectionable to some bishops, that independence also helps sustain the broad historic voice of Catholicism in public affairs. It is a diverse profile, from small colleges that are quite insular, to large liberal arts colleges and research universities that are very much engaged with the wider culture. Furthermore, their political and theological profiles vary enormously: some have embraced traditionalist efforts to reinstate a tightly defined Catholic orthodoxy while others have fused rather acritically with the mainstream culture of American higher education, and still others have embraced Catholic teaching on social justice as defining their central mission.

These complex internal dynamics too often obscure what is in any case an impressive profile in higher education: 236 Catholic colleges and universities, spread out across all 50 states, enroll more than 900,000 students and represent a rich pluralism of emphases and identities within an at least potentially unifying Catholic vision of contemporary life [26]. Enrollment grew by almost $61 \%$ between 1980 and 2005. This strong institutional presence does not necessarily translate into effective identity-formation processes. We simply do not know a great deal about whether these colleges and universities are effectively passing on a Catholic ethos, spirituality, vision, and social commitment (in whatever terms a given observer defines those things) or simply reproducing the values of the wider society. However, they have certainly shaped generations of American leaders in church, society, business, politics, and the legal system. The best data come from $[33,34]$ and raise important doubts about the efficacy of current church practice in this regard.

Finally, church-sponsored communications media remain an important aspect of the Catholic public profile. The focus and technological basis of the media used continue to shift: a Catholic media profile that once emphasized magazines, newspapers, and radio, today increasingly emphasizes different media $[35,36]$. Catholic television stations and websites now abound, and the Vatican now projects a sophisticated Internet presence. Thus, though such publications as America, First Things, the National Catholic Reporter, the National Catholic Review, and The Wanderer continue to be read and 
to exercise significant influence in their particular markets, the broader Catholic market appears increasingly to belong to television and the Internet.

Good studies of this shifting religious media terrain are rare, but a few generalizations seem warranted. First, and perhaps most importantly, all these media outlets combined appear to have lost market share to the dynamic growth of two other sectors of religious media; Evangelical media and magazines reach out to a broad mass market across nearly all regions and social sectors. Additionally, a smaller set of media outlets promote "contemporary spirituality" of Buddhist, Hindu, Sufi, Sikh, "new age", and other varieties, especially among the future societal leaders being educated in elite universities and socialized in urban centers. Second, Catholic television appears to be dominated by traditionalist Catholicism, with programming devoted to some of the least intellectually reflective pietistic practices of contemporary Catholicism and to the most sectarian Catholic intellectuals. This programming both reflects and promotes an authentic part of the current spectrum of Catholic practice; its dominance nonetheless reflects a dearth of much televised presence of other points on that spectrum. Third, the Catholic Internet presence is far more diversified, better reflecting the broad "catholic" spectrum of views and emphases; here, conservative and liberal positions, official and alternative Catholic voices, and clergy and lay perspectives all find a voice.

Two final notes regarding ecclesial institutions. First, under John Paul II the Vatican built a multilingual online presence via an official website, which has since been extended to a YouTube channel, and sophisticated social media capacity-a capacity that Pope Francis has used to strong effect. The USCCB has done likewise in English and Spanish. Both have made official teachings more directly available in forms accessible to lay Catholics. However, this will only serve to advance ecclesial insight and influence if it is accompanied by a parallel effort to foster dialogue within the Church and critical engagement across perspectives and cultures, in ways capable of shaping democratic dynamics in the public arena [37]. Second, political historians have shown that the most influential civil associations in American history have been built on "federated" organizational forms combining intensive local participation with state- and national-level structures [37]. The Catholic structure of parishes, (arch)dioceses, state conferences, and the national bishops conference creates precisely such a federated structure, suggesting that the Catholic tradition might still be capable of articulating a strong external voice vis-à-vis American public life. Again, for such a voice to be effective, legitimate, and authentically Catholic, it must emerge from long-term symbiosis between authoritative central teaching and decentralized lay initiative, both appropriately affirming the pluralistic principles of a democratic public arena. Pope Francis and in particular his Pontifical Council for Justice and Peace appear to be committed to fostering such symbiosis, as evidenced by their strong central interventions in debates on climate change and economic inequality combined with their repeated calls for grassroots action on a global level and the convening of a series of "World Meetings of Popular Movements" [15].

\subsection{Other Public Institutions}

Beyond the official and semi-official ecclesial institutions discussed above, individual Catholic leaders in prominent positions in other public institutions also project public Catholicism into the wider society. These include a wide variety of Catholic intellectuals teaching and writing from within high-profile universities, a small portion of them holding endowed chairs of Catholic Studies and many more embedded in traditional professorial roles, as well as intellectual Catholic journalists such as E. J. Dionne and Ross Douthat [38,39]. Second, Catholics have come to play a remarkably prominent position in the court system of the United States, particularly at the level of the U.S. Supreme Court, where two-thirds of the justices are Catholic [40]. Third, Catholic elected officials continue to exert influence at all levels of American government, from schools boards, city councils, and mayors' offices to the halls of Congress; we know little about the preponderant direction of this influence, given the diversity of political views of Catholic politicians.

What all this will add up to in terms of future electoral influence is difficult to predict: the Catholic vote swung toward Barack Obama in 2008 and 2012, despite assertive episcopal intervention 
against him due to his stance on abortion, gay marriage, and later "religious freedom". Only future elections will show us whether this simply reflected widespread disenchantment with the Republican Party following the Iraq disaster, the bungling of Hurricane Katrina relief, and the "Great Recession," or began a long-term shift back to voting for Democratic candidates. If the latter is the long-term pattern, research will be needed to assess whether it results from a widespread turning away from episcopal authority, or from heightened lay political discernment exercised autonomously but in dialogue with episcopal authority. That outcome likely depends partly on how the bishops choose to lead in the years ahead-and on the work of grassroots Catholics in social movements to mobilize church teachings on a variety of terrains.

\subsection{Lay-Centered Movements}

At the grassroots level, a wide variety of lay-centered movements are shaping the cultural terrain of American Catholicism. Some of these are familiar, such as the pro-life/anti-abortion movement, which is partly episcopally funded and draws on Catholic parish life in significant ways. A variety of Catholic social justice movements such as Pax Cristi and movements for solidarity with human rights activists in other societies, although only weakly present in most parishes, engage students at public and Catholic universities via campus ministry efforts, worship at "Newman Centers", and issue-specific outreach efforts. The Catholic charismatic movement and other apostolic movements continue to exert an important influence, both through local parishes and in less institutionally organized venues [41]. Meanwhile Opus Dei, Catholics United for the Faith, and other conservative movements seek to bolster more traditionalist interpretations of Catholicism, lobby for "restorationist" interpretations of Vatican II, and pressure bishops and priests to clamp down on liberal trends within American Catholicism. On the more liberal side, movements such as Call to Action, Catholics United, and Catholic Alliance for the Common Good seek to heighten the profile of Catholic social teaching on a variety of issues, and to press for changes in Catholic teaching and authority structures. All these are important and understudied facets of public Catholicism.

A less well-known - but perhaps more important due to its role in public Catholicism-lay-centered movement also plays a significant role in American Catholic life. Many Catholic parishes in low-income urban areas, and some suburban and rural parishes, participate actively in "faith-based community organizing" efforts (FBCO, also known as broad-based or congregation-based community organizing). Community organizing has received recent attention due to Barack Obama's early experience in Chicago, but such efforts have for more than six decades involved Roman Catholic, historic black Protestant, liberal and moderate Protestant, Jewish, Unitarian, and (more recently) Pentecostal congregations in work to influence local and state-level public policy. They have built a track record of influencing public policy to benefit low- and middle-income communities on such issues as public education, economic development, housing, healthcare, and policing. Sponsoring most of this work are several national FBCO networks, including the PICO National Network; the Industrial Areas Foundation; the Gamaliel Foundation; Direct Action, Research, and Training; and the regional Inter-Valley Project and Ohio Organizing Collaborative; plus a few independent efforts. These networks link more than 190 local coalitions present in 40 states, essentially all major metropolitan areas, and many other primary cities of the country. In the past decade, the FBCO field has been analyzed insightfully by both scholars [42-53] and practitioners [54-57]. The field had grown dramatically over the prior decade, with $42 \%$ more coalitions in 2011 than in 1999 . The typical FBCO coalition brings together roughly two dozen organizational members (mostly religious congregations, but also labor unions, immigrant organizations, neighborhood associations, and others); it then trains leaders from within those organizations to identify and advocate for policies that better serve poor, working-class, and middle-income communities [42].

As of 2011, for which systematic national data exist, those organizations incorporated 4150 member institutions (about $80 \%$ of which are religious congregations, the rest mostly unions, public schools, and neighborhood associations). More than a quarter of the sponsoring congregations 
are Catholic parishes. A third of governing board members and paid organizers are Catholic, as are $42 \%$ of coalition directors/lead organizers. When well implemented, this organizing model empowers lay leadership reflective of Vatican II's emphasis on the laity's mission "in the world."

FBCO work on issues has often reflected the public policy priorities embodied in Catholic social teaching as articulated in papal and American episcopal statements. That is no coincidence: for 35 years, the bishops' Catholic Campaign for Human Development has been the most consistent source of funding for faith-based community organizing efforts throughout the country; many religious orders also fund this work. While CCHD funding now only represents about $15 \%$ of funding for local FBCO coalitions (down from 19\% in 1999), that support has been crucial to strengthening the field's organizational infrastructure. Almost two-thirds of coalitions receive CCHD funding in a given year, and CCHD often provides the start-up funding that has helped the field grow from a scattering of struggling organizations in the early 1980s to its current wide geographic profile. This Catholic involvement has shaped the ethos of the field in significant ways. For example, whereas the governing boards of most civil society organizations heavily over-represent well-off constituencies, $22 \%$ of FBCO governing board members have household incomes under $\$ 25,000 /$ year and fully half have household incomes under $\$ 50,000$ /year-the latter almost exactly representative of U.S. households. This strong representation of low-income leadership almost certainly results from CCHD sponsorship: the organization insists that funded organizations include substantial leadership by low-income people themselves. Likewise, over half of board members are non-white.

Two other important lay movements are also not widely recognized: the many small "faith sharing" groups functioning within or alongside Catholic parishes, and the grassroots movement Voice of the Faithful. The faith-sharing groups are decentralized and reflect many different strands of Catholicism, typically meeting weekly or monthly to read scripture, reflect on their faith lives, pray together, and (more rarely) engage in service or advocacy work together [58]. Voice of the Faithful argues for increased accountability of episcopal structures and a greater lay share in church leadership, partly in response to the sexual abuse crisis. Though sometimes perceived as hostile to church leaders, the organization appears to combine strong Catholic religious identity, a desire for a thriving institutional profile for public Catholicism, and insistence on greater transparency and accountability.

As carried in ecclesially-linked institutions, other public institutions, and lay movements, public Catholicism thus enjoys an impressive profile in American public life. Whether through their direct governance or through inspiration and teaching, the bishops shape all these dimensions of Catholic public presence. However, whether it all adds up to significant Catholic influence on American society today is less clear. Indeed, in its direct impact, public Catholicism often seems to add up to less than the sum of its parts. In order to understand the complex place of the Catholic tradition within the American democratic arena, the next section analyzes the role of public Catholicism in one crucial national debate of recent years.

\section{Case Study of Public Catholicism: The Healthcare Reform Debate}

The 2009-2010 national healthcare debate, along with the health reform efforts preceding it, offers a glimpse into public Catholicism in action. As has been widely noted, the recent debate follows decades of efforts to broaden healthcare coverage in American society. The U.S. bishops had long supported egalitarian access to healthcare, and already in 1981 had issued a major pastoral letter strongly endorsing some form of universal coverage, giving as the first principle to guide national health policy that "every person has a basic right to adequate healthcare" [59]. Despite that advocacy, the desire (of the bishops and others) for broad health reform had remained largely frustrated by the difficulties inherent to reshaping a sector that, by the end of the century, made up nearly a sixth of the national economy. The bishops weighed into the national debate again with a major public resolution in 1993, and with official press releases and voter education efforts in 2002, 2004, and 2006 [60,61]. 
Over the years, other Catholic public actors also weighed in on the issue, including the Catholic Health Association, various Catholic politicians and intellectuals, and a variety of religious orders.

However, all this had gained little traction. That began to change as the nation's health crisis worsened, as children's health became a wedge issue for broader calls for health reform, and when one of the faith-based community organizing networks described above set expansion of healthcare access as one of its primary goals. I focus attention here on the third factor, due to its links to public Catholicism and because the first two factors have been widely reported.

As it first sought to influence national policy, the PICO National Network could draw on the experience of its sophisticated statewide effort in California. PICO California had been active in organizing for broad healthcare access for several years, and its affiliate in San Jose had been central in winning passage of the nation's first legislation to cover all children in a county (the Santa Clara County Health Initiative). Out of these initiatives, in May 2005 some 315 PICO leaders met in Washington, DC, to begin building PICO's national strategic capacity. After meeting with about one hundred Congressional representatives, staffers, and DC-based policy think-tanks, they recommended to local affiliates that healthcare become the initial focus of national organizing [62].

Eventually, PICO became a key part of an alliance of groups working for major national expansion of coverage for uninsured children and their parents, focused on the re-authorization of the State Health Insurance Program (SCHIP) scheduled for 2007. In alliance with other organizations, PICO mobilized the primary religious voices that brought faith-based moral framing into the congressional debate $[57,63]$.

In retrospect, this framing of the policy debate within faith-based language appears to have been important, but in one sense secondary: the Catholic bishops and other religious voices had, after all, been providing such moral framing for years. The PICO National Network's distinctive role emerged as it amplified, diversified, and gave urgency to that faith-based moral framing, but also gave "political legs" to it: through its ability to organize people to articulate the case for children's healthcare coverage in the nation's capital and, crucially, in congressional home districts, PICO's organizing federations in 15 states and some 100 congressional districts (roughly split 55\% Democratic and $45 \%$ Republican) made the case for bipartisan support for SCHIP expansion. Several times in 2005-2007, PICO brought two to five hundred leaders from low- and moderate-income communities to Washington, DC. In March 2007 alone, these constituents reportedly held 68 meetings with their U.S. Senators and Representatives and another 85 meetings with congressional staff. PICO also worked to move the policy conversation out of the Beltway: local affiliates held 47 town hall meetings and press conferences in congressional representatives' home districts, and claim to have generated more than 10,000 phone calls and 6700 emails to those representatives regarding SCHIP. Public letters arguing for healthcare coverage for children were delivered to Congress and the White House in December 2006 (with 200 clergy signees) and September 2007 (with 1900 clergy signees). The media provided public exposure to wider audiences, both locally and nationally, via 112 separate stories in local, regional, and national newspapers, plus in-depth stories featuring PICO leaders on National Public Radio and the PBS News Hour [64-67].

Ultimately, the SCHIP debate was advanced by the combination of: (1) authoritative religious framing of the healthcare issue in moral terms provided by the Catholic bishops and other national leaders of faith communities; (2) the PICO National Network's ability to provide convincing political "legs" and a prophetic edge to that moral voice; (3) the wider alliance of secular and faith-based policy think-tanks, advocacy groups, and organizing projects that spearheaded the drive to shift the debate from simple re-authorization of the program to significant expansion of children's health coverage; and (4) the Congressional leadership's decision to make SCHIP re-authorization a legislative priority. The efficacy of this alliance is signaled most clearly by hard dollars: in 2006 the discussion revolved around whether $\$ 12$ billion could be provided for reauthorization and by early 2007 the debate had shifted to bipartisan congressional support for $\$ 35$ billion to underwrite SCHIP expansion. Twice (October 2007 and March 2008) the alliance worked with SCHIP champions in Congress to pass major SCHIP 
expansions with bipartisan support, but twice the law was vetoed: neither PICO nor the wider alliance could overcome opposition to expanding government's role in healthcare.

The inability to overcome these presidential vetoes was a significant setback that could have demobilized the effort, but in retrospect it is clear that it laid the moral and political groundwork for a significant victory: in early 2009, having made comprehensive healthcare reform a centerpiece of the presidential campaign, the new Obama administration made SCHIP expansion one of its first legislative priorities, and legislation was passed by Congress almost immediately and signed into law on 4 February 2009. At the signing ceremony in the White House, PICO leaders sat in the front row, flanking both sides of Michelle Obama, as President Obama signed the legislation. PICO's announcement of the signing thanked its "key child health allies who helped make this victory happen," and listed the U.S. Conference of Catholic Bishops among those allies [68].

The passage of SCHIP represented partial implementation of the moral vision of healthcare carried in Catholic social teaching and for which the American bishops had argued for decades. However, despite the difficulty of this struggle, children's healthcare would turn out to have been the easy issue. The bigger issue of comprehensive reform remained on the horizon, but had become imaginable with the change of presidential administrations: the Obama administration followed up the SCHIP signing with an effort to move legislation forward that would fundamentally reshape healthcare delivery and provide near-universal coverage.

As Congress struggled through much of 2009 to forge some kind of bipartisan healthcare agreement, the United States Conference of Catholic Bishops once again weighed in on the public debate, in favor of reform but insisting that it be guided by specific principles. In place of the broad overarching principles of some of the earlier documents (solidarity, subsidiarity, etc.), the bishops specified three principles that they wanted to shape healthcare reform [69]. First, they noted that "reform should make quality healthcare affordable and accessible to everyone," i.e., that it include effective coverage for the poor and working class. The bishops' position on affordability was developed in close consultation with PICO, and closely reflected that network's policy language. Second, the bishops noted it was "essential" that healthcare reform "clearly include longstanding and widely supported restrictions on federal funding of abortion and protections for rights of conscience." Third, the bishops strongly urged that immigrants receive access to adequate healthcare regardless of their immigration status. The bishops' position-strong support for deep reform of healthcare, but with affordability, immigrant access, and protection of the legal status quo on abortion as guiding principles-would be reiterated repeatedly throughout the healthcare debate.

As debate raged in mid-2009, fueled by the early "tea party" protests, policy stagnation seemed to set in: the entire reform effort was stuck between liberal insistence on a full "public option" and libertarian protests that had effectively killed the public option. Meanwhile, the PICO National Network and its affiliates were already engaged in extensive educational efforts, and PICO had launched a website devoted to its healthcare work, providing comprehensive information regarding various denominations' stances in support of reform and resources for congregational study groups and religious leaders' sermons related to the topic. PICO, and its allied organizations Faith in Public Life (interfaith), Sojourners (evangelical Christian), and Catholics in Alliance for the Common Good (Roman Catholic), had already become the primary religious voices in a broad health reform coalition [68]. To break the policy impasse, in August 2009 PICO held a "National Faith-Based Day of Action" involving 50 prayer vigils and reform rallies in 18 states, specifically intended to counter what organizers viewed as the uncivil and anti-reform character of public debate [70]. PICO and the three organizations listed above also launched a high-profile organizing campaign and an advertisement on religious television. In the "40 Days for Health Reform" campaign, PICO mediated into the national public arena the human stories of doing without healthcare, told in local leaders' own voices through testimony before Congress and in national press conferences.

These efforts helped counter the policy stagnation and put health legislation back on track, but Congressional support for healthcare reform remained razor thin. In two cliffhanger votes, the fate of 
healthcare legislation ultimately hung on the votes of a handful of pro-life congressional members of the House of Representatives-many of whom were Catholic. This group of about a dozen lawmakers was led by Representative Bart Stupak, a Catholic who explicitly tied the group's votes on health legislation to their opposition to federal funding of abortion services. Another central player in the debate was the Speaker of the House, Nancy Pelosi, also Roman Catholic but strongly favoring women's access to abortion services. The first vote (7 November 2009) led to the extraordinary situation described by the New York Times as follows:

On Friday (November 6), Ms. Pelosi met twice with Democratic lawmakers from the Pro-Choice Caucus. In between, she huddled with staff members from the bishops conference (USCCB), Mr. Stupak and two other leading Roman Catholic lawmakers, Representative Mike Doyle, Democrat of Pennsylvania, and Representative Brad Ellsworth, Democrat of Indiana. The representatives of the nation's bishops made clear they would fight the bill if there were no restrictions on abortion. In an extraordinary effort over the last 10 days, the bishops conference told priests across the country to talk about the legislation in church, mobilizing parishioners to contact Congress and to pray for the success of anti-abortion amendments. The bishops sent out information to be "announced at all Masses" and included in parish bulletins, and urged priests and parishioners to tell House members: "Please support the Stupak Amendment that addresses essential pro-life concerns." They added: "If these serious concerns are not addressed, the final bill should be opposed." In the end the abortion opponents had the votes, and Ms. Pelosi yielded, allowing Mr. Stupak to offer his amendment.

The Stupak amendment passed relatively comfortably (240-194), with support from pro-life Democrats and most Republicans, despite some consideration among Republicans of voting against the amendment as a way to defeat the overall health legislation [71]. With this settled, the overall healthcare reform legislation passed 220-215.

As the legislation moved to the Senate, the potential impact of the Stupak amendment was a matter of sharp debate: supporters argued that it preserved the longstanding status quo represented by the "Hyde Amendment" of 1974, whereby no federal funds appropriated through Health and Human Services can be used to pay for abortion services. They also argued that this coincided with the policy preferences of most Americans, who continue to oppose governmental funding of abortion even as they support women's access to it under some circumstances. Opponents argued that, by prohibiting abortion services being provided via any insurance that is paid or subsidized by federal funds, and given the broad impact of the healthcare reform bill on existing health insurance programs, the Stupak amendment would take away abortion coverage already in effect, and thus change the status quo. The complex nuances of the amendment's impact allowed both sets of advocates to frame the issue as a mortal threat to their supporters. Abortion thus re-emerged as the potential third rail of health reform, lethal no matter how it was handled.

In December 2009, the Senate passed the overall healthcare reform bill, but without the Stupak language. In its place, the Senate version of the bill included language for which Senator Ben Nelson-a Methodist and long-time pro-life ally of the Catholic bishops-negotiated, neither requiring nor prohibiting funding for abortion services, but: (1) requiring insurance companies to segregate premium monies that would cover such services, thus keeping federal money separate and (in some sense) not "paying for" abortion; and (2) allowing individual states to exclude abortion coverage in the state-based insurance "exchanges" created in the health reform legislation. Thus, as of the start of 2010, two versions of health reform were on the table; that both included language restricting federal funding for abortion provides evidence of the significant weight of public Catholicism in political deliberation. However, which would prevail?

The contrasting House and Senate versions-and particularly their divergent language on abortion coverage-led directly to the second cliffhanger vote. By early 2010, larger political dynamics dictated that health reform would only move forward by a two-step process: the House would approve the 
Senate bill without changes, then immediately pass further legislation "fixing" specific problems (including one central to the Catholic bishops' position-providing funding to make health insurance more affordable to low-income Americans). In this situation, the precise Stupak language was dead and Republican opposition to the healthcare reform package was unanimous, so the entire heathcare vote hung on whether an accommodation on abortion language could be found that kept pro-life Democrats (many of them Catholic) on board. In the balance: the fate of health legislation sought by every Democratic president since Harry Truman (1944-1952), projected to expand coverage to some 32 million uninsured Americans, subsidize care for the poor and the working class, improve prescription drug benefits for the elderly, eliminate insurance industry practices widely seen as abusive, and do so while lowering federal deficits over the next 10 years $[72,73]$.

However, also in the balance was a key goal of the American Catholic bishops for several decades: a health bill that would dramatically expand access to healthcare, while respecting other elements of Catholic teaching. Regarding the latter, recall that in addition to abortion and the "conscience clause", the bishops had focused attention particularly on affordability and the rights of immigrants. The final bill was a mixed bag on these two concerns, effectively addressing affordability but barring undocumented immigrants from the new health insurance exchanges and leaving in place a five-year ban on even legal immigrants from Medicaid. However, as the final vote approached in mid-March 2010, the politics of it were clear: passage would dramatically expand affordability and empower those in Congress likely to support subsequent immigration reform, while defeat would empower those in Congress most opposed to the bishops on matters of immigration. What the health reform bill would do on abortion - that third rail of healthcare reform - was still open to interpretation and negotiation even in the days leading up to the final vote.

Here, public Catholicism spoke with several voices: the USCCB remained opposed to anything short of the Stupak language, and thus refused to endorse the final bill. If Catholic legislators and their allies adopted this position, it would effectively kill the reform effort, since there appeared to be no other way for the legislation to pass in the current Congress. However, other Catholic institutions weighed in as well. Three emerged most prominently in public discussions. First, the Catholic Health Association, which had argued throughout the debate for health reform meeting the three USCCB criteria, issued a statement implicitly endorsing the bill up for a vote [74-80]. Second, an organization named "NETWORK: A Catholic Social Justice Lobby" issued a strongly-worded endorsement signed by the Leadership Conference of Women Religious and the heads of more than 50 women's religious orders that together include more than $95 \%$ of American nuns [81]. Third, Catholic public intellectuals also endorsed the final bill in explicitly Catholic terms, most prominently the Washington Post columnist E.J. Dionne, Jr. [82]. As noted above, these voices of public Catholicism carry differing degrees of authority within the Church, with the bishops holding official authoritative power. However, in the public arena, this distinction is not so clear: public Catholicism spoke in a complex voice representing various views, all appealing to democratically elected congressional representatives on the basis of Catholic worldviews and commitments. It also seems likely that at least some portion of the bishops themselves were loathe to go down in history as having been central actors in killing healthcare reform; presumably, they were pleased that some Catholic voices provided cover for Catholic legislators wanting to support the bill.

Ultimately, it was those congressional representatives who had to vote for or against the final legislation. That vote came on the evening of 21 March 2010. At the insistence of the pro-life members of Congress led by Representative Stupak, President Obama agreed that afternoon to issue an executive order clarifying that the bill authorized no use of federal funds to pay for abortion. With this step, Stupak and several others agreed to support the final bill. That night the bill passed on a 219-212 vote, and was signed into law later that week [83-86].

Thus, health reform came to the United States after decades of failed efforts and intense debate over what precisely would constitute "reform". That debate will continue, over implementation questions (such as the new law's impact on abortion and how immigrants are to receive medical care 
in the new health marketplace) and over ethical questions (including the debate on the law's impact on abortion). My purpose here is not to engage in those debates, but rather to analyze the dynamics of public Catholicism both within and beyond the great health reform debate of 2009-2010. Before doing so in depth, I note several features that seem clear from the foregoing analysis.

First, the "Catholic contribution" to the debate was both enormous and complex. The overall weight of public Catholicism clearly pushed in favor of substantial reform within strong ethical guidelines. The USCCB strongly and consistently spoke to Catholics and policymakers about the dimensions of health reform that the Church would support. The final issues in the debate were partly focused around key areas of Catholic concern, with Catholic voices very much "in the room," itself a significant achievement. The diversity of Catholic voices in the legislative end game reflected with reasonable accuracy the complexity of the moral, fiscal, societal, and human implications of tinkering with the massive health sector-and the political complications that inevitably came into play when restructuring a huge sector of the American economy during an election year. Some Catholic leaders will praise the final result while others will criticize it as either too weak on abortion protections or too weak on universal coverage. However, it seems incontestable that Catholic voices rooted in authentically Catholic concerns and commitments-from the USCCB and individual bishops to grassroots organizations-significantly influenced the health reform debate.

Second, various Catholic actors skillfully used their institutional resources to shape the debate. Through USCCB press releases, conversations with policymakers, and requests that local parishes make announcements and distribute information at key moments of the debate, the bishops made their position clear and mobilized constituents in support of it. Significantly, they did so repeatedly over the course of nearly a year of focused debate. Similarly, the CHA and the women's religious congregations utilized their networks to support reform and intervened at strategic moments to publicly buttress their allies in Congress-and, in the legislative end game, arguably created the crucial political space for Catholic legislators to support the final bill.

Third, together with its secular and religious allies, the PICO National Network brought into the public arena an effective set of faith-based voices from poor, working, and middle-class communities. Furthermore, those voices contributed powerfully to a successful pilot run at healthcare reform (the SCHIP re-authorization) and to moving comprehensive healthcare reform through the congressional process. PICO's role reflects the Catholic connections of faith-based community organizing noted above, but also transcends them: the organization brought people into the public arena as citizens rooted in poor to middle-class communities and as people of a variety of faith traditions, not as sectarian Catholics. Yet PICO's overall thrust (in favor of reform that significantly expanded health coverage and made it affordable for poor folks) clearly reflected the emphases of its core religious constituencies: Catholic as well as Jewish synagogues, and liberal to moderate Protestant, Unitarian, and African-American and Latino Pentecostal churches. In that sense, PICO's work during much of the debate bridged between public Catholicism, the public voices of other religious traditions, and the democratic public arena.

Fourth, where the teachings of those core constituencies differed, PICO remained silent. The organization never endorsed or opposed a specific bill. Embracing the Catholic bishops' final position would have alienated the organization's liberal Protestant, Jewish, Unitarian, and some Pentecostal constituents. Rejecting that position would have alienated some of the organization's Catholic constituents. Instead, in the final legislative push PICO encouraged its members to seek guidance in their own religious tradition's statements on the topic. In this sense, although PICO represented a salient voice of Catholicism (and other faith traditions) through much of the debate, in the political end game that role fell to other figures and organizations.

Fifth, the various voices of public Catholicism, though largely united during most of the debate, differed acutely in their assessments of the final legislation. Although that diversity of public views contributed to final passage of health reform, it also reflected a certain incoherence in American 
Catholicism today. I suggest below that this incoherence is rooted in divergent understandings of authority and the nature of the Church-though not in the ways one might expect.

Finally, one must wonder how the health debate has re-shaped the overall impact of public Catholicism. Presumably, the experience deepened the reservoir of democratic skills, policy expertise, and public orientation at many of the levels of public Catholicism summarized in Figure 1 above. Additionally, high-profile involvement in this debate may have strengthened public Catholicism's political capital for future policy debates. If that is the case, it was hard to discern in subsequent battles regarding immigration reform, though perhaps nothing could have overcome Tea Party intransigence on that terrain. Alternatively, the USCCB and Catholic bishops may have lost considerable political capital by staking their final position on healthcare reform on what some-including some figures within public Catholicism who appear to have been acting in good faith-regarded as a tendentious and perhaps partisan interpretation of the final healthcare bill. Only ongoing political events will make clear which has actually occurred, but one fairly immediate way to gauge this lies in these events' impact on figures of "public Catholicism" within Congress. Initial signs included Bart Stupak's decision not to seek re-election, the result of his demonization by pro-life political forces, despite his having gone to bat repeatedly for pro-life provisions in the healthcare bill. One interpretation: the bishops' ultimate position on healthcare reform-portrayed by some as intransigent and by others as prophetic-made it impossible for their own allies to navigate the complex cross-currents of public life and remain viable for public office. The bishops' stance simply offered no cover for their own allies to make the prudential judgments and political compromises that are inevitable in a democratic public arena. Thus, while the overall Catholic influence in the healthcare debate (from the USCCB and other voices) certainly appears to have strengthened the strategic position of public Catholicism, the bishops' failure to provide their allies with public room to maneuver appears to have weakened the position of public Catholicism—and perhaps that of the bishops themselves [87].

However, the healthcare debate can only show us so much; to gain greater perspective, I step back from that specific debate to examine broadly the dynamics of public Catholicism in America today.

\section{Analyzing Institutional and Cultural Dynamics}

Analyzing three additional institutional and cultural arenas will offer further insight into the nature of Catholicism within American public life. These arenas are leadership in mediating institutions; authority dynamics; and the culture of worship, prayer, and spirituality.

\subsection{Institutional Leadership}

Catholicism has a rich intellectual tradition of thinking broadly about how laypeople contribute to public life via leadership in civil and political institutions. Separately, whole subfields of social science and organizational management analyze the roles of institutions and organizations in shaping society, especially through what sociologists have long called "mediating institutions" or "voluntary associations". Here, I note only a few insights important for thinking about public Catholicism.

In the future, public Catholicism will be influential to the extent that it: (a) at the level of national politics decisively leaves behind a model whereby the bishops or the USCCB strive to unilaterally define truth; (b) at the level of political society advocates for those Catholic ideals for which a democratic consensus or working coalition can be built; and (c) at the level of civil society lays the cultural foundations for future coalitions by mediating into American culture a more intense encounter between mainstream culture and those Catholic ideals that now stand outside it. In the latter encounter, Catholicism will have to challenge contemporary consumerism's idolization of individual autonomy. That task is made more complex by the fact that Catholicism-despite its fundamental commitment to a pro-social and communitarian vision of the human person [88,89]—has itself been affected by the idolization of individual autonomy, with the attendant rise of heterodox expressions of Catholicism committed to economic libertarianism, including within Congress. To be a fully credible interlocutor at all these levels of a democratic and rights-affirming public arena, public Catholicism 
must clearly signal its affirmation of modern standards of personal rights and democratic norms-not a simple task due to remaining vestiges of pre-modern Catholicism at times still influential within the Church. Pope Francis appears committed to eliminating the influence of both heterodox economic libertarianism and pre-modern traditionalism, but it is too early to judge whether he will succeed at either.

Crucial for shaping public Catholicism's future will be the presence of engaged Catholics as leaders of mediating institutions at all levels of society, from local non-profits to national civil associations, from neighborhood associations to state political parties to Congress, from school teachers to international scholarly associations, and from family businesses to major corporations (i.e., the middle level of Figure 1). Such leadership roles in differentiated institutional sectors are too myriad to discuss coherently as a group here, much less to coordinate nationally through some national Catholic structure. Nor would such central coordination be desirable, as it would almost surely be too rigid and authoritarian to be acceptable in a democratic public arena. Rather, public Catholicism will be coordinated via Catholic teaching and inspiration and via citizens' discernment in democratic dialogue with the wider culture. Catholics already occupy many leadership roles in which this occurs, and more will do so in the future as Latino Catholics, in particular, move into higher-level leadership in American society. Catholics in positions of institutional leadership can serve as bridges between the Catholic tradition and American institutional life, to the extent that they are deeply immersed in the former and capable of bringing their resulting worldview insightfully to bear within secular institutions, inspired and informed by the teaching role of the bishops but also by American democratic ideals.

The efficacy of lay Catholic leaders in this bridging role will be shaped crucially by higher education. In one sense, there is nothing new in this: for generations, Catholic leaders have sought to use universities to train laypeople for leadership in the secular world, and the Second Vatican Council reaffirmed the centrality of this dimension of lay vocations in Gaudium et Spes. However, two recent shifts make this yet more central. First, as educational levels have risen throughout American society, a university degree followed by postgraduate studies or professional credentialing has become the gateway to institutional leadership in most sectors of society. Second, as Catholic lay leaders have attained higher levels of education and embraced democratic and professional sources of authority, they expect a more consultative relationship with the Church hierarchy. As illustrated by the health reform debate, educated laypeople who exert autonomous authority in mediating institutions simply will not respond to the assertion of a central command-and-control model of clerical or episcopal authority. The days of that model of American public Catholicism are likely gone forever, at least as long as the United States remains an educated and democratic republic.

The most crucial mediating institutions for shaping public Catholic leaders of the future will be universities, both Catholic and public. Catholic universities obviously matter, since they most directly embody and teach Catholic ideals, however imperfectly. Public universities and their attached Catholic ministries will be at least as crucial—and perhaps more so: in purely demographic terms public universities simply touch the lives of huge numbers of young Catholics, especially from the less-privileged sectors that Catholic social teaching seeks to make central agents of social transformation. In addition, public university settings incorporate important parallels to the situation that will be faced later in life by Catholic lay leaders of secular institutions: in both settings, Catholic leaders take the values and social commitments learned from their tradition and bring them to bear within more pluralistic and secular settings. Bridging successfully across that institutional divide is a learned skill, and public universities with strong Catholic campus ministries offer students experience in precisely that kind of cross-institutional engagement.

\subsection{Authority Dynamics: Church and Sect in American Catholicism}

Authority is central to understanding Catholicism's relationship to American public life because, within any society, the various forms of authority represent "alternative processes by which values are allocated, styles by which decisions are made, and objects to which deference and obedience 
are rendered" [90]. More broadly, authority represents one of the core "social forms" or constitutive building blocks upon which communities and societies are built [91-95].

American culture rests uneasily on a tension between two relationships to authority. On one hand, it rests on the knee-jerk rejection of all authority in pursuit of the "unencumbered self" free of all restraints on its liberty [96]. However, the self unencumbered of all restraints and all authority is markedly unstable and subject to manipulation by external agents. So, paradoxically, American culture rests also on unquestioning acceptance of external authority, in the form of populist demagoguery, media "experts," and cultural icons-which are then drawn on to (authoritatively) reject the legitimacy of public authority. The political dynamics of recent presidential elections show that paradox in full color. In the early 21st century, American culture sails precariously between the Scylla that rejects all authority beyond the self, and the Charybdis that unreflectively accepts manipulative authority. These do not correspond in any simple sense to "liberal" and "conservative" political or theological positions. While liberals tend toward Scylla, they sometimes accept authority rather blindly (U2's Bono, Bernie Sanders, and until recently Barack Obama); and while conservatives sail toward Charybdis, they have their own authority-rejectionists (Tea Partiers and libertarians). Thus, if Catholicism offers a different understanding and practice of authority than other American cultural strands, then, in addition to shaping views on specific issues, public Catholicism may become crucial for the wider American culture by promoting more constructive ways of relating to authoritative figures [97-99].

The key here rests in the last phrase, "authoritative figures," for it allows an alternative to American culture's uneasy shifting between endless flight from authority in pursuit of the unencumbered self and vesting blind authority in external agents. Rather, authority can reside in the complex flow between the personal judgment of individuals with relative autonomy in their own lives, and authoritative figures to whom deference is given in recognition of greater insight or experience or knowledge [100]. Such deference might be limited to specific areas, such as that given to medical personnel or scientists; or it might be more general, such as that given to the Dalai Lama, Mother Theresa, or Rick Warren by those who see each as an authoritative figure. In either case, between authoritarianism and radical autonomy lies a realm in which authoritative relations can be combined with personal judgment and control of one's life. The Catholic ethos and structure of episcopal teaching authority vested in the bishops, appropriated with careful discernment, potentially offers much of value on that terrain.

To look for positive dynamics of authority within the Catholic Church will strike some as outrageous, amidst ongoing revelations of Catholic abuse of authority, both through sexual abuse by clergy and through related episcopal malfeasance. Yet I suggest that American Catholicism, inchoately and partially, has indeed begun to generate a set of practices and self-understandings that treats authority as substantive, authoritative, and self-transcending, without violating individual responsibility for decision-making, moral discernment, and political judgment. We saw glimpses of this in the healthcare debate, but it is a far more widespread phenomenon in contemporary Catholicism.

With this suggestion, I certainly do not imply that Catholicism has fully outlived the legacy of obeisance to religious authority that it inherited from the pre-modern past. Religious authoritarianism remains a significant strand within Catholicism, in sectors of both the hierarchical structure and a laity that yearns for simple definitions of truth from above. Any fair assessment must recognize that American Catholicism retains strands that would deny any moral autonomy to the individual. Nor do I imply that Catholicism has remained unaffected by the powerful cultural force of hyper-individualism in American life-any fair assessment must also recognize that (like all religious traditions) Catholicism on American shores has internalized elements of radical individualism that in practice reject all moral authority beyond the self [101].

Alongside these patterns, however, American Catholicism is germinating a different and important set of authority dynamics. This should not surprise us: given its communion with the long sweep of Catholic history, its institutional structure, and its practice of at least weekly Eucharist, American Catholicism carries a strong communitarian counterweight to cultural individualism [55]. 
Likewise, given American Catholics' embeddedness in the American cultural commitment to individualism, we should not be surprised that American Catholics have developed resources for autonomous moral discernment. More generally, the Catholic intellectual tradition's understanding of authority (considerably more complex than the tradition's too-frequent recourse in practice to simple obeisance to authority) stands in significant tension with the culture of American individualism. If these germinating dynamics can be nurtured—by the bishops and others within the Church-into a healthy future of a lay-clerical-religious-episcopal relationship on the basis of authoritative but not authoritarian teaching, public Catholicism may have much to offer American political culture.

Space precludes me from fully redeeming this suggestion, beyond noting that recent analyses do so for me. Exemplars from a liberal perspective include the works by Michele Dillon and Jerome Baggett showing moral decision-making grounded in Catholic principle and sacraments, yet with the locus of authority linked also to individual autonomy [20,21]. From a conservative direction the interrogation of episcopal authority by self-described traditionalists such as Richard John Neuhaus, George Weigel, Michael Novak, and perhaps most thoughtfully by Robert P. George has the same effect: insistence on moral and theological discernment by active individual intellects that are both in communion and tension with hierarchically defined truth.

That current cultural and ecclesial pressures drive progressive, liberal, conservative, and traditionalist church members in the direction of lay-clerical dialogue reflects a powerful cultural logic underlying global Catholicism today: the strong claims of authoritative teaching embedded within longstanding institutions and spiritual practices, combined with modernity's strong current of individual empowerment. That these cross-pressures so frequently produce incoherent spiritual chaos does not necessarily mean that they cannot ultimately resolve in a coherent authoritative culture [102]. The recent scandals, as well as the internal Church tensions revealed in the health reform debate, were already moving public Catholicism in such a direction, even before Francis' papacy moved dramatically forward on this front.

None of this analysis should suggest that American Catholics have gotten authority dynamics "right". Catholics struggle mightily to balance the roles of authoritative teaching and personal judgment in Catholic lives and structures. However, to the extent American Catholics can "get it right" in balancing healthy individualism and communitarianism, authority and autonomy, Catholic culture can contribute to reconstructing the wider society's tenuous relationship to accountable authority. To the extent Catholics do so both in their personal faith lives and in the public arena, they can contribute to reconstructing a coherent and critical authoritative culture both within the Church and in the wider society. The dynamics of authority are thus crucial at all levels of Figure 1.

We saw this struggle played out very publicly in the debate over healthcare reform detailed above. Some analysts no doubt will emphasize the diversity of Catholic viewpoints in the final debate, while others will emphasize the fundamental unity of principles underlying those viewpoints. Among the former, some will celebrate this diversity of viewpoints as one of the great strengths of public Catholicism, allowing complex discernment of policy in a complex social world; while others will decry the diversity of viewpoints as reflecting incoherence and bad faith among some Catholic public actors. At risk of being lost in that debate is an insight about the current situation among one set of key actors within public Catholicism: the American Catholic bishops themselves. For this observer, looking back at that debate, it is hard to deny a certain episcopal incoherence-not among the bishops themselves, since any disagreements there were well-shielded from public view. Rather, I detect a certain incoherence between the historic tone and content of public Catholicism in America, discussed above, and the tone and content of some bishops' interventions in the public arena [103-105].

The point may be made most clearly by invoking the sociological distinction between "Church" and "sect" [106]. Religious leaders operating within a self-understanding as "Church" operate with an eye toward pragmatism, maximizing possible gains in public policy, as judged through the lens of their own religion but always in dialogue with other views, and recognizing the trade-offs with competing social goods that cannot be built into policy now but may be attained later. In contrast, 
religious leaders operating within a self-understanding as "sect" operate with an eye toward absolute definitions of the good, with public policy judged as an all-or-nothing affair, as a matter of purity rather than pragmatism. During the course of much of the healthcare debate, the USCCB's role struck this observer as a remarkably savvy and principled "Church"-based intervention in the public arena, operating appropriately within Catholic understandings of authoritative teaching and the norms of a democratic public sphere. However, during the end game, as the policy process moved toward a final vote, what had seemed a symphony of episcopal intervention in public life suddenly seemed off-key: the insistence on the specific Stupak language that would have doomed the overall health reform effort. At least for this observer, it seemed out of tune with the historic Catholic understanding of politics in a fallen world, where progress requires accepting partial victories in order to lay the groundwork for future gains. Such a stand might have qualified as prophetic if the alternative were clear violation of Catholic norms, but alternative language on abortion and conscience protection was available (and had been negotiated by the bishops' allies in the Senate).

In these circumstances, the final decision to oppose healthcare reform appeared either partisan or sectarian. Though some individual bishops may have wandered into blind partisan identification, overall I discount the partisan explanation: little in Catholic self-understanding lends itself to unproblematic partisan identification with either major political party in America today. Rather, these events suggest a deeper and more troubling dynamic that may be at work within the American Catholic episcopacy: in their desire to be prophetic and principled, some bishops may be unconsciously willing to shed longstanding Catholic self-understanding as truly a Church, both theologically and sociologically. If true and if it continues, this would mark an extraordinary shift away from ecclesiological orthodoxy, with unknown and likely deleterious consequences.

However, any episcopal shift toward Catholic sectarianism is unlikely to go unchallenged. Presumably, significant sectors of the Catholic leadership recognize the dangers of such a shift-the danger of squandering potential influence on public policy, the danger of discrediting public Catholicism more generally, the danger of positioning the Catholic Church as just another sect within a crowded landscape, and the danger of being unfaithful to historic Catholic self-understanding as a Church. If such a sectarian tendency exists within the American episcopacy, much of the future of public Catholicism will depend upon whether it is fostered or countered by Catholic leaders-papal, episcopal, clerical, religious, and lay. Many of Pope Francis' more assertive moves appear designed at least indirectly to counter Catholic sectarianism, but much will depend on how his initiatives and vision are appropriated and implemented within American Catholic structures. During his papal visit to the United States in September 2015-and even more so during the World Meeting of Popular Movements in Bolivia in June 2015-Francis has sought to intervene in public life via dialogue with political representatives and civil society; this is the new twist that he brings to global public Catholicism, an apparently deep-seated confidence in participative democracy rather than more exclusive forms.

If public Catholicism is to thrive in the contemporary public arena, it must be built upon an authoritative culture that can engage educated citizens, including Catholics, people committed to other faiths, secularists, and spiritual humanists. So perhaps the single most fundamental challenge facing American Catholicism in the 21st century lies in learning how to effectively confront the hyper-individualism of American culture while simultaneously shedding the Church's own clerical authoritarianism inherited from the past, and countering any implicit shift toward Catholic sectarianism. All these facets of contemporary American Catholicism were on clear display among Catholic leaders at the November 2015 USCCB meetings of the American bishops. Some bishops spoke clearly in favor of a more dialogical process-both internally and vis-à-vis current social issues through their Faithful Citizenship guide for voters during the 2016 elections-while others denounced any such change of direction, sometimes in terms that appeared to break from the normal standards of civil exchange among episcopal leaders $[107,108]$. The Roman Catholic Church in the United States will be working out these tensions for some time to come; in this author's view, perhaps the most hopeful sign 
of the potential to do so comes via those advocating a more "synodal" approach to church governance that links authoritative and dialogical processes, led by none other than Pope Francis himself [109].

This leads us to the next analytic level, for getting authority right involves the cultural practices of worship, prayer, and spirituality.

\subsection{Culture of Worship, Prayer, and Spirituality}

How might constructive dynamics of authority play out in contemporary Catholicism? The days are clearly gone when Catholic leaders could issue authoritative pronouncements and expect American Catholics to simply follow them. If such a time in fact ever existed, its death knell was sounded sometime between Humanae Vitae in 1968 and the recent sex-and-authority scandals. Yet Catholic teaching continues to shape members' worldviews and values. As Jerome Baggett [8] shows, even in the hotbed of liberalism called the San Francisco Bay Area, Catholics in the pews come to their moral and ethical views in a dialogical relationship with the magisterium. That is, American Catholics are not simply "cafeteria Catholics" picking and choosing teachings that they like. Rather, at least the more reflective among them arrive at their moral and ethical views by listening to a variety of "voices" in the surrounding culture, from politicians to church leaders, from peers to popular music, and from bible study groups to talk radio. Some even read official Church teachings about the issues. They evaluate these sources in relationship to their intuitions about the moral life and their own lived experience, and gradually build their moral lives in light of that emergent process. Michele Dillon (op. cit) likewise demonstrates this process of moral decision-making, framing it explicitly within democratic theory, as the reflexive process through which Catholic teaching develops over time to meet new challenges.

Thus, to the extent that the bishops and other Catholic leaders can draw Catholics into dialogue with the Church's teaching via preaching, adult formation classes, the Catholic media, precisely to that extent will the authority of Catholic teaching actually shape the lives of mature adult Catholics. Such individuals will not and cannot simply adhere unthinkingly to Catholic tradition handed down from above; this would violate the very nature of being a mature adult in the contemporary world.

Though this may risk a fair degree of moral messiness as people find their way-and surely infuriates those who advocate a more deductive, rule-following approach to the moral life-at its best it brings a reflective quality to moral formation that respects the maturity of adult Catholics, and affirms their responsibility for their own spiritual lives. In a world of individual empowerment, the Church might well aspire to make its teaching more clearly the primary voice within this discernment, but it will have to do so not by fiat but by building its own moral credibility and the plausibility of its authoritative teaching. In any case, whether or not church leaders like this style of moral discernment, it appears to be the dominant mode among a broad swath of American Catholics serious about their faith commitment, especially among those positioned (by education and by leadership skills) to actively engage the secular world. Regardless of the ultimate fate of Francis' reforms, to spite this approach would be to reject out of hand some of the most dedicated and mature American Catholics from which the Church draws financial support and leadership (both elite and grassroots).

On this view, the wrong way forward would be the sectarian one, trying to compel intellectual assent to magisterially prescribed public policy, or to directly induce more rigorous adherence to moral rules flowing from that teaching. On such a path, public Catholicism in American life will likely be destined to wither: powerful demographic, educational, and cultural trends will dilute the effectiveness of any such approach. Those advocating such a path for public Catholicism do so in hope of transforming American culture, but risk disconnecting Catholic teaching from the actual personal and societal lives of most Catholics, and thus becoming irrelevant to all but a few.

An alternative path lies in affirming the present capacity and future promise of mature Catholic adults-lay, religious, and clergy — to responsibly internalize their faith tradition and carry it into the world not as subservient followers but as thoughtful adherents (which implies sometimes being critical adherents). In shaping lay Catholics fully capable of this role, the central stage must be taken by the 
identity-shaping role of Catholic ministry: in its core pastoral work, the Church shapes identities via faith formation classes, small faith sharing groups, adult discussion groups, and especially worship with its shared prayers, music, preaching, and Eucharist. Education can train better-informed Catholics, and to a certain degree shape their identities and worldviews. However, recent cognitive science confirms a key insight of the social sciences: the core processes of identity formation occur via repetitive ritual processes that tap into brain regions reflecting our deep evolutionary development $[110,111]$. In Catholic terms, those ritual processes involve worship and liturgy in community, and their internalization at the individual level in prayer and spirituality.

A fundamental challenge for the Catholic bishops will be to foster the cultural dynamics and authoritative relationships that form such strong, engaged, and thoughtful "public Catholics". Here, the Catholic culture of liturgical worship, sacramental practice, and spiritual formation represents crucial resources. Parishes-where most Catholics receive the Eucharist, hear the Word, baptize their children, marry their spouses, bury their dead, and pray their way through good times and bad-are the crucial institutional spaces for these identity- and culture-shaping dynamics. At the bottom of Figure 1, the identity-formation processes that occur through practices of worship, prayer, and spirituality are thus foundational. Unless Catholicism can be made meaningful there by dynamically engaging everyday Catholics on terms relevant for their daily lives, public Catholicism will be built on hollow foundations.

Public Catholicism is thus partly founded upon the culture of worship, prayer, and spirituality that is the heart of thriving parishes. If these parish-based religious dynamics richly engage Catholics, the overall tradition can advance as a source of authoritative insight in modern adherents' lives. Such a role need not undermine the authority of the episcopacy in ecclesial leadership—indeed, on this terrain lies the bishops' best opportunity for vigorous promotion of public Catholicism. However, it does call into question the rigid boundary definition whereby strong and assertive lay leadership is perceived as a threat to clerical authority. This model reflects the central role of "the sense of the faithful" long recognized as a key partner of episcopal authority $[112,113]$. Such an internal dynamic might produce a church less focused on internal power struggles over authority, focused instead on external engagement with the world, with such engagement facilitated by a constructive internal model of collaborative authority.

In sum, whether public Catholicism thrives or withers in American society will be shaped by complex dynamics occurring at multiple levels and differing time horizons. At the highest level, and with the most obvious and immediate impact, are the public actions of bishops and Catholic leaders of elite institutions, how these actions are covered by the media, and how these leaders exert direct influence on the rest of American society. At the lowest level and with the longest timeline are the dynamics of authority and processes of identity formation rooted in mass culture and the worship lives of local parishes. In between lies the role of universities, university-linked ministries, and parish-based faith formation programs in shaping future leaders of mediating institutions, thus bringing Catholic values, ethos, and worldview into the democratic public arena.

\section{Conclusions: Whither the "Catholic Moment"? American Public Catholicism's Bright and Foreboding Future}

In 1987, Richard John Neuhaus famously diagnosed a distinctive "Catholic moment," in which the Catholic Church was uniquely and fortuitously positioned to influence American culture in profound ways [114]. In the quarter-century since then, that moment has taken a severe beating. The clerical sex scandal harmed basic trust in the clergy and episcopal hierarchy, the primary face of the Church in most Catholics' lives. The associated authority scandal at least temporarily undermined many Catholics' assumption that the Church would protect its members and its core spiritual vocation in the world, when these things were in tension with immediate institutional self-protection. Additionally, the willingness of some members of the episcopacy and clergy to narrow Catholic teaching in a way that appears to serve the narrowest of partisan interests-most commonly Republican interests, but 
in other settings Democratic interests-has diminished the integrity and transcendence of one of the tradition's richest intellectual resources. The latter pattern risks transforming Catholicism from church to sect, and giving up entirely on wide Catholic cultural influence.

Yet an important Catholic moment may endure. The institutional and cultural presence of the Catholic tradition in American life makes its public role significant. The tradition's continuing intellectual depth, (usually) non-sectarian ethos, constructive engagement with competing religious traditions, and voice on key questions facing contemporary society make its public role important. The world's contemporary situation makes the Church's public role in the United States vital. Democracy faces vast challenges in the 21st century, in the U.S. and elsewhere. The U.S. remains a standard-bearer of democratic ideals, albeit imperfectly and all too often hypocritically. America will only succeed in addressing its democratic challenges via active engagement with diverse ethical traditions. Roman Catholicism clearly represents one such ethical tradition, and the bishops the crucial voice of that tradition.

The birds-eye analysis in this article can hardly do justice to the complexity of the American bishops' role or of public Catholicism generally. However, it provides enough empirical and analytic framing to say a little about the contemporary moment in American Catholicism and its place in public life.

Most obviously, it seems clear that the Catholic Church remains enormously well positioned to influence public debate across a variety of issues. With a strong institutional presence in neighborhoods, the educational field, the legal and political systems, and public communications media, the potential Catholic voice in the societal conversation underlying American democracy is impressive. This is all the more true given the status of American Catholics as an important swing constituency in national elections, as well as the Catholic Church's presence (though by no means hegemony) among Latinos, the largest emerging ethnic vote now and in coming decades.

The importance of this potential Catholic voice is multiplied again by the fact that current Catholic teaching cuts against the grain of American popular culture in a number of salient areas, from the death penalty to international diplomacy, from pre-natal and end-of-life issues to the nature of a just economy, and from sexual morality to the rights of undocumented immigrants. This author, the reader, the bishops, other Catholic institutional leaders, and the mass of American Catholics surely do not agree on all these issues. That is not the point. Rather, the point is that democratic deliberation needs diverse viewpoints to be represented in both politics and civil society. Democratic deliberation within American politics and the wider culture will better face these issues if they draw on thoughtful and divergent voices. The Catholic tradition represents one strong, thoughtful voice on these issues, and one in significant tension with contemporary culture on some of them. This tension makes it all the more important. The American bishops are uniquely positioned to articulate the tradition, if they do so in ways appropriate to a democratic arena.

Much more problematic for making the Catholic voice effective within that societal conversation is a very different tension between Catholicism and contemporary culture: the tension between divergent understandings of authority outlined above. At its worst, that tension becomes a dialogue of the deaf, across an unbridgeable gulf that separates those bishops, priests, and lay leaders firmly ensconced in a traditionalist subculture and their peers (in the Church and in the wider society) who simply will not abide command-and-control authority within the democratic arena. Transcending this gulf will only be possible if divergent players recognize differing authoritative claims and if the public voices of American Catholicism-beginning with the bishops-speak consistently in authoritative rather than authoritarian tones.

On the model of democratic deliberation outlined above, accepting the democratic public arena need not marginalize Catholic truth claims. Rather, the Catholic voice becomes one set of claims about what is true, what is meaningful, and what is the best way forward in social policy. The Catholic public voice is well positioned to be influential if it is articulated in authoritative tones in keeping with ecclesial self-understanding as "Church," rather than in more authoritarian and sectarian tones. When spoken 
with confidence born of faith, intelligence born of deep Catholic intellectual resources, a humane tone born of Catholic pastoral experience, and appropriate humility born of acceptance of the democratic rules of the game, such a voice could be profoundly influential in democratic deliberation. Indeed, it might generate a better, more humble, and more influential "Catholic moment." This assertion is premised on the idea that reflective adults and mature communities can actually value authoritative voices that respect their maturity of discernment and appropriate autonomy of decision-making —and that those unschooled in reflective decision-making can learn those skills and orientations. In contrast, public claims made in a more sectarian tenor may gain an immediate following, but within a healthy democratic public arena they ultimately prevail only in the rarest of cases. Nothing indicates that recent Catholic strategy is one of those cases.

Thus, a stark choice faces the leaders of public Catholicism in the United States in the years ahead. Such leaders obviously include individual bishops, but they also include Catholic intellectuals, lay institutional leaders within church structures and in the wider society, the heads of religious orders, local priests, and religious women and men. On what model of Catholic authority are we going to proceed in the future? Public Catholicism has extensive institutional resources to offer as the United States and the Catholic Church confront their respective challenges. However, the cultural resources within public Catholicism can lead it to play a healthily critical and constructive role, premised on the complex authority dynamics within a church that fully engage the wider society; or to play a narrowly sectarian role, premised on an understanding of authority exported from the Church's internal life to the wider society, but which is not viable within a modern democratic polity.

An appropriate understanding of the parallel structures of authority operative within Church and society-mutually recognizing the other's legitimacy in its own context-can help leaders of public Catholicism effectively operate in the public arena. In doing so, they can offer the wisdom of the Catholic tradition to American society as it seeks to define its future. Doing so can also help leaders of public Catholicism to gradually revise Catholic self-understanding in light of the tradition's ongoing experience in history. Something akin to this is clearly the inspiring vision that animated the Second Vatican Council and the papacy of Francis I.

A deep irony thus lies in the American Catholic situation. In its most thoughtful and constructive mode, the Catholic understanding of authority may represent the tradition's crucial potential contribution to American and global culture in the 21st century. Yet, when pulled in more sectarian directions, the Catholic understanding of authority undermines the Church's very credibility as a contributor to modern democratic dialogue, and thus undermines public Catholicism itself.

So the state of public Catholicism is a crucial matter both for the internal life of the Church, for the external health of society, and for the societal conversation that constitutes democratic deliberation. Internally, if American Catholicism fails to integrate lay, clerical, and episcopal leadership-both male and female-within dynamics of authority mutually recognized as legitimate by mature Catholics, ongoing conflicts over authority will continue to undermine the coherence and plausibility of any public Catholic voice. On the other hand, if the bishops can successfully lead such integration, the coherence and impact of public Catholicism in the future may be impressive. Externally, given the model of democratic deliberation outlined above, such an articulate and effective public Catholicism may contribute to American society in important ways: by adding significant depth and insight to moral-political discussions; by providing moral resources for new kinds of democratic political action in favor of marginalized members of society; and by contributing to a new synthesis of personal autonomy and communitarian authority in American culture. A Catholic moment may endure-but if so, it must simultaneously be humbler and more confident, less triumphal and yet fully engaged in public life. In short, it must be more "catholic" in both its ecclesiology and its politics. 


\section{Abbreviations}

The following abbreviations are used in this manuscript:

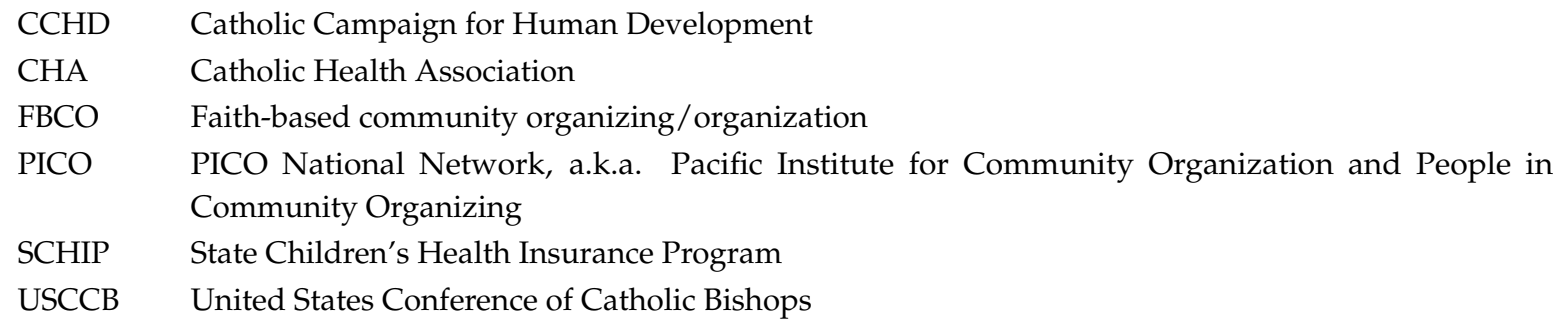

Acknowledgments: Thanks to the Louisville Institute and the Lilly Endowment for support that contributed to this article, as well as colleagues in the "Future of Catholicism Project"; a broader version of this article may in the future be published as part of that project. Thanks also to colleagues in the wider world of academe, professional organizing, and the church-including the University of New Mexico, the Graduate Theological Union, the University of Notre Dame, and Duke University—all of whom offered criticism and insight. Finally, thanks to three anonymous reviewers and the editors at Religions for insightful and helpful criticism of the original draft-but all views and analyses are those of the author.

Conflicts of Interest: Wood serves as a pro bono advisor to the Catholic Campaign for Human Development, a major anti-poverty initiative of the United States Conference of Catholic Bishops. He has done research on and spoken widely within various faith-based community organizing efforts, some of which have been funded by the CCHD. Since 2014, Wood also serves as a pro bono member of the national governance board of the PICO National Network.

\section{References and Notes}

1. On the roles of these figures in the development of american Catholicism, see David J. O'Brien. Public Catholicism, 2nd ed. Maryknoll: Orbis Books, 1996.

2. José Casanova. Public Religions in the Modern World. Chicago: University of Chicago Press, 1994, Note that the sectors analyzed here are divided differently than Casanova's theoretical division of the public sphere into levels of state, political society, and civil society.

3. For an important analysis of public Catholicism from a conservative angle, see George Weigel. Soul of the World: Notes on the Future of Public Catholicism. Washington: Ethics and Public Policy Center and Eerdmans, 1996.

4. In addition to [2], a key source in contemporary democratic theory regarding the public sphere is Jeffrey C. Alexander. The Civil Sphere. Oxford and New York: Oxford University Press, 2006.

5. Seyla Benhabib. "Models of Public Space: Hannah Arendt, the Liberal Tradition and Jurgen Habermas." In Habermas and the Public Sphere. Edited by Craig Calhoun. Cambridge: MIT Press, 1992.

6. Jean L. Cohen, and Andrew Arato. Civil Society and Political Theory. Boston: MIT Press, 1992.

7. Nancy Fraser. "Rethinking the Public Sphere: A Contribution to the Critique of Actually Existing Democracy." In Habermas and the Public Sphere. Edited by Craig Calhoun. Cambridge: MIT Press, 1992.

8. Jürgen Habermas. The Theory of Communicative Action: Volume II. Boston: Beacon Press, 1987.

9. Jürgen Habermas. The Structural Transformation of the Public Sphere: An Inquiry into a Category of Bourgeois Society. London: Polity Press, 1989.

10. Jurgen Habermas. “A 'Post-Secular' Society-What Does That Mean? " Reset Dialogues on Civilizations, 2008. Available online: http://www.resetdoc.org/EN/Habermas-Istanbul.php (accessed on 7 June 2013).

11. Margaret R. Somers. "What's Political or Cultural About Political Culture and the Public Sphere? Toward an Historical Sociology of Concept Formation." Sociological Theory 13 (1995): 113-44. [CrossRef]

12. Margaret R. Somers. "Narrating and Naturalizing Civil Society and Citizenship Theory: The Place of Political Culture and the Public Sphere." Sociological Theory 13 (1995): 229-74. [CrossRef]

13. Alfred Stepan. "Religion, Democracy, and the 'Twin Tolerations'." Journal of Democracy 11 (2000): 35-57. [CrossRef]

14. These themes occur throughout Jorge Bergoglio's public interventions since becoming Pope Francis, but see especially Laudato Si'. "Encyclical Letter Laudato Si' of the Holy Father Francis on Care for Our Common Home." Available online: http://w2.vatican.va/content/francesco/en/encyclicals/documents/ papa-francesco_20150524_enciclica-laudato-si.html (accessed on 10 October 2015). 
15. Pope Francis. "Speech at the World Meeting of Popular Movements." 9 July 2015. Available online: http:/ /en. radiovaticana.va/news/2015/07/10/pope_francis_speech_at_world_meeting_of_popular_movements / 1157291 (accessed on 10 October 2015).

16. Thomas Massaro, and Thomas A. Shannon. American Catholic Social Teaching. Collegeville: Liturgical Press, 2002.

17. Charles E. Curran. Catholic Social Teaching, 1891-Present: A Historical, Theological, and Ethical Analysis, Moral Traditions Series. Washington: Georgetown University Press, 2002.

18. Kenneth R. Himes, and Lisa Sowle Cahill. Modern Catholic Social Teaching: Commentaries and Interpretations. Washington: Georgetown University Press, 2005.

19. For the classic portrayal of the earlier Catholic subculture and its emergence into being part of mainstream American society, see Will Herberg. Protestant, Catholic, Jew: An Essay in American Religious Sociology. Garden: Anchor Books, 1960.

20. Jerome Baggett. Sense of the Faithful: How American Catholics Live Their Faith. New York: Oxford University Press, 2009.

21. Michele Dillon. Catholic Identity: Balancing Reason, Faith, and Power. Cambridge and New York: Cambridge University Press, 1999.

22. Robert N. Bellah, Richard Madsen, William M. Sullivan, Ann Swidler, and Steven M. Tipton. Habits of the Heart: Individualism and Commitment in American Life. Berkeley: University of California Press, 1985.

23. Gerhard Lohfink. Jesus. Community: The Social Dimension of Christian Faith. Philadelphia and New York: Fortress Press and Paulist Press, 1984.

24. John Courtney Murray, S. J. We Hold These Truths: Catholic Reflections on the American Proposition. Kansas City: Sheed and Ward, 1960.

25. The key statement from the Second Vatican Council through which the Church embraced Murray's understanding is "Gaudium et Spes: The Pastoral Constitution of the Church in the Modern World." Statement issued by the worldwide Catholic bishops gathered in Rome on 7 December 1965. Available online: http://www.vatican.va/archive/hist_councils/ii_vatican_council/documents/vat-ii_cons_19651207_gaudiumet-spes_en.html (accessed on 7 July 2014).

26. All data in this paragraph and the next come from The Official Catholic Directory, 1967-2007. New Providence: P.J. Kenedy \& Sons, 2008.

27. All data in this paragraph come from The Official Catholic Directory, Anno Domini 2008. New Providence: P. J. Kenedy \& Sons, 2009, p. $2069 \mathrm{ff}$.

28. See Francis Butler. "Address to the National Leadership Roundtable on Church Management." Origins 36 (2006): 132-34.

29. Data here come from Center for Applied Research in the Apostolate. "2008 Survey of Allegations and Costs: A Summary Report for the Secretariat of Child and Youth Protection." In 2008 Annual Report of the Office of Youth \& Child Protection. Washington: Georgetown University, 2009. Available online: http://www.usccb.org/ocyp/annual_report2008.shtml (accessed on 15 March 2010).

30. Estimates of payouts from sexual abuse settlements vary; one reliable source reports over $\$ 2$ billion as of early 2010. “Pope Offers Apology, but No Punishment." New York Times, 20 March 2010.

31. Elsewhere I have suggested how the bishops might more strategically draw on their sponsorship of anti-poverty efforts to rebuild their public credibility; see Richard L. Wood. "Up from the Parishes: Reclaiming the Public Voice of Catholicism." American Catholic Studies 1 (2003): 1-10.

32. David Yamane. The Catholic Church in State Politics: Negotiating Prophetic Demands and Political Realities. Lanham and Oxford: Rowman \& Littlefield, 2005.

33. Christian Smith, and Patricia Snell. Souls in Transition: The Religious and Spiritual Lives of Emerging Adults. Oxford University Press: New York and Oxford, 2009, see especially Chapter 4: "Religious Affiliations, Practices, Beliefs, Experiences, and More"; pp. 103-42.

34. On spirituality on elite college campuses, see Courtney Bender. The New Metaphysicals: Spirituality and the American Religious Imagination. Chicago: University of Chicago Press, 2010. Not all the spiritual alternatives necessarily undermine Catholic formative influence, in that some may be combinable with Catholic practice and identity. But they may, by exposing Catholics to diverse traditions, reduce the centrality and efficacy of Catholic identity-formation. Or such exposure may actually heighten the centrality of Catholic identity formation for some Catholics while diluting it for others. 
35. Catholic Radio Association. Available online: http://www.catholicradioassociation.org/about-us/ (accessed on 5 May 2015). CRA coordinates a loose network of Catholic radio stations nationally, as a kind of trade association. The Catholic Academy for Communication Arts Professionals links Catholic radio professionals. CRS data suggest that approximately 150 self-identified Catholic radio stations existed at the end of 2007, and noted that CRA was involved in helping submit applications for 220 others. Less data exists regarding Catholic television; the author could identify only 14 clearly Catholic stations in the United States, most affiliated with (arch)dioceses. But this appears to severely undercount both the number of stations and their influence: The Catholic Television Network, for example, is seen via cable service in 7 states, including the most populous states in the nation, as well as on the Internet. The best known Catholic TV is Mother Angelica's EWTN, which broadcasts internationally. Most Catholic TV represents the strongly conservative and traditionalist end of the contemporary spectrum of American Catholicism, not always in concert with the American bishops. In addition, more than a dozen Catholic-affiliated "production centres" for producing television content exist; these represent a much broader spectrum of American Catholicism, though how broadly telecast the resulting content may be remains unknown..

36. In recent years, international Catholic leaders appear to have become more reflective regarding their presence in the new media. See for instance the reflections of Federico Lombardi, S. J. "Perspective on the Problems of New Communications." Origins 39 (2009): 91-95. Certainly, Pope Francis has shown extraordinary awareness of the role of social media in the contemporary world.

37. Theda Skocpol, Marshall Ganz, and Ziad Munson. "A Nation of Organizers: The Institutional Origins of Civic Voluntarism in the United States." American Political Science Review 94 (2000): 527-46. [CrossRef]

38. E. J. Dionne's regular columns for the Washington Post from a thoughtful Catholic liberal perspective are available online: https:/ / www.washingtonpost.com/people/ej-dionne-jr (accessed on 8 January 2016).

39. Ross Douthat's regular columns for the New York Times from a thoughtful Catholic conservative perspective are available online: http:/ / www.nytimes.com/column/ross-douthat (accessed on 8 January 2016).

40. For more on these patterns, see Barbara A. Perry. "Catholics and the Supreme Court: From the 'Catholic Seat' to the New Majority." In Catholics and Politics: The Dynamic Tension between Faith and Power. Edited by Kristin Heyer and Mark Rozell. Washington: Georgetown University Press, 2008, pp. 155-74.

41. On the Catholic charismatic movement, see Mary Jo Neitz. Charisma and Community: A Study of Religious Commitment within the Charismatic Renewal. New Brunswick: Transaction Books, 1987.

42. For an overview of faith-based community organizing nationally, see Brad Fulton, and Richard L. Wood. "Interfaith Organizing: Emerging Theological and Organizational Challenges." International Journal of Public Theology 6 (2012): 1-23. [CrossRef]

43. Richard L. Wood, Brad Fulton, and Kathryn Partridge. Building Bridges, Building Power. Boulder: Interfaith Funders, 2012. The field-wide data in this and the following paragraph come from these sources, based on the National Study of Community Organizing Coalitions.

44. For an in-depth analysis of the religious dynamics within this field, see Richard L. Wood. Faith in Action: Religion, Race, and Democratic Organizing in America. Chicago: University of Chicago Press, 2002. On organizing in a Catholic context, see [31].

45. On the field's work for racial equity and racial justice, see Richard L. Wood, and Brad Fulton. A Shared Future: Faith-Based Organizing for Racial Equity and Ethical Democracy. Chicago: University of Chicago Press, 2015; the last chapter presents a model of deep social reform consonant with contemporary Catholic social teaching.

46. On the impact of community organizing on parishes and other faith communities, see Mary Ann Flaherty, and Richard L. Wood. Faith and Public Life: Faith-Based Community Organizing and the Development of Congregations. New York: Interfaith Funders, 2004. Available online: http://hdl.handle.net/1928/10664 (accessed on 28 January 2016).

47. Luke Bretherton. Resurrecting Democracy: Faith, Citizenship and the Politics of a Common Life. Cambridge and New York: Cambridge University Press, 2015.

48. Donna C. Day-Lower. Prelude to Struggle: African American Clergy and Community Organizing for Economic Development in the 1990's. Lanham: University Press of America, 2002.

49. Stephen Hart. Cultural Dilemmas of Progressive Politics: Styles of Engagement among Grassroots Activists. Chicago: University of Chicago Press, 2002.

50. Paul Osterman. Gathering Power; The Future of Progressive Politics in America. Boston: Beacon Press, 2003.

51. Jeffrey Stout. Blessed Are the Organized. Princeton: Princeton University Press, 2010. 
52. Heidi Swarts. Organizing Urban America: Secular and Faith-Based Progressive Movements. Minneapolis: University of Minnesota Press, 2008.

53. Mark R. Warren. Dry Bones Rattling. Princeton: Princeton University Press, 2001.

54. Edward T. Chambers, and Michael A. Cowan. Roots for Radicals: Organizing for Power, Action, and Justice. New York: Continuum, 2003.

55. Michael Gecan. After America's Midlife Crisis. Boston: MIT Press, 2009.

56. Dennis A. Jacobsen. Doing Justice: Congregations and Community Organizing. Minneapolis: Fortress Press, 2001.

57. Gordon Whitman. "Beyond Advocacy: The History \& Vision of the PICO Network." Social Policy 37 (2007): 50-59.

58. For rich data and insightful analysis, see Robert Wuthnow. I Come Away Stronger: How Small Groups Are Shaping American Religion. Grand Rapids: W.B. Eerdmans, 1994. Although now rather dated, Wuthnow's analysis still captures important dynamics within small faith-sharing groups.

59. United States Conference of Catholic Bishops. Health and Health Care: A Pastoral Letter of the American Catholic Bishops. Washington: United States Conference of Catholic Bishops, 1981, p. 17.

60. See for example United States Conference of Catholic Bishops. A Framework for Comprehensive Health Care Reform: Protecting Human Life, Promoting Human Dignity, Pursuing the Common Good. Washington: United States Conference of Catholic Bishops, 1993.

61. The bishops in the USCCB regularly reiterated their position, including in an important letter from the to Congress on 10 January 2010. Available online: http://wwwmigrate.usccb.org/issues-and-action/ human-life-and-dignity/health-care/upload/health-care-letter-to-congress-2010-01-26.pdf (accessed on 28 May 2013).

62. For more on PICO's state- and national-level organizing effort and the strategic capacity underlying it, see Richard L. Wood. "Higher Power: Strategic Capacity for State and National Organizing." In Transforming the City: Community Organizing and the Challenge of Political Change. Edited by Marion Orr. Lawrence: University of Kansas Press, 2007, pp. 162-92. Wood did research as a participant-observer at the May 2005 meetings, and interviewed leaders, did fieldwork, and otherwise monitored subsequent developments.

63. The data in this paragraph come from a PICO source: Gordon Whitman. "Why SCHIP Sank? Lessons for the Coming Battles. "(unpublished manuscript from 2008, shared with the author). Wood followed these developments as they were occurring, and often verified key claims by monitoring coverage in local media as events were covered there.

64. Bernie Becker. "Obama Casts Health Effort in Moral Terms.” New York Times, 19 August 2009.

65. Cyrus Sanati. "Protests Planned for Banks' Shareholder Meetings." New York Times, 8 April 2010.

66. David Waters. "Immigration Reform Avocates to Pray, Rally and March in Washington." Washington Post, 19 March 2010.

67. Christi Parsons. "Obama Plan Would Curb Health Insurers on Rate Hikes." Los Angeles Times, 22 February 2010.

68. The allies in the SCHIP struggle identified in the announcement were the "Georgetown Center for Children and Families, Center on Budget Policy and Priorities, First Focus, Families USA, Community Catalyst, American Academy of Pediatrics, National Council of Churches, Sojourners, U.S. Catholic Conference of Bishops (sic), and other religious denominations." Available online: http:/ / www.coverallfamilies.org/news?id=0005 (accessed on 10 May 2012). At later stages, allies included the Service Employees International Union, the American Cancer Society Cancer Action Network, the American Diabetes Association, the American Heart Association, the American Nurses Association, Consumers Union, and the National Association of Community Health Centers.

69. Slight variations in the formulation occurred throughout 2009 and early 2010, depending on the emerging state of the policy debate. The formulation quoted here comes from a USCCB letter to Senators dated 30 September 2009. Available online: http://www.usccb.org/sdwp/national/2009-09-30-healthcareletter-senate.pdf (accessed on 8 May 2012).

70. “Cover All Families" website. Available online: http://www.coverallfamilies.org/pages?id=0021 for a state-by-state listing of these events, and to view the national advertisement put out by the coalition (accessed on 10 September 2013). 
71. There have been scattered reports, difficult to verify, that the Catholic bishops weighed in to keep Republicans in line in support of the Stupak Amendment, rather than using it as a tool to sink overall healthcare reform (which the bishops of course supported, as long as it included no funding for abortion). Available online: http:/ / newmexicoindependent.com/41634/gop-sees-\%E2\%80\%98win-win $\%$ E2\%80\%99-as-stupaksplits-dems (accessed on 28 September 2015).

72. “Obama's Remarks in Iowa City on Healthcare." Available online: http:/ /www.nytimes.com/2010/03/26/ us/politics/26obama-text.html (accessed on 26 January 2016).

73. "New Healthcare Bill." Available online: http://www.cnn.com/2010/POLITICS/03/21/health.care for initial news analysis of the bill (accessed on 3 March 2011). The deficit-reduction claims made for the bill are the least verifiable element of the analysis.

74. In fact, the Catholic Health Association had begun to diverge from the USCCB analysis of the emerging health reform bill in December 2009, when it endorsed the Senate's approach. For the initial statement by the CHA, its later reiteration of support for the final legislation, and its endorsement by NETWORK. Available online: http:/ /www.nytimes.com/2009/12/26/health/policy/26abort.html?_r=1\&_r (accessed on 10 March 2011).

75. Carol Keehan. "The Time Is Now for Health Reform." Catholic Health World. Available online: http://www. chausa.org/The_time_is_now_for_health_reform.aspx (accessed on 10 March 2011).

76. "Network statement on health reform." Available online: http://www.networklobby.org/press/3-14-10 HealthcareReform.htm (accessed on 10 March 2011).

77. For the statement by the women's religious congregations, see NETWORK: A Catholic Social Justice Lobby. "Catholic Sisters Support Passage of Healthcare Bill." Available online: http://networklobby.org/ legislation/catholic-sisters-letter-support-healthcare-reform-bill (accessed on 26 January 2016). In essence, the CHA and NETWORK argued that the Senate language - crafted by pro-life Senators-adequately protected the longstanding Hyde Amendment provisions against using tax dollars to pay for abortion. The USCCB disagreed.

78. Michelle Boorstein. “Dissent among Catholics Seen as Nuns' Groups Back Health Bill." Washington Post, 18 March 2010.

79. David M. Herszenhorn, and Robert Pear. "Final Votes in Congress Cap Battle on Health Bill." New York Times, 25 March 2010.

80. On the NETWORK intervention and the way differing Catholic views were brought to bear in public deliberation, see Helene Cooper. "Nuns Back Bill Amid Broad Rift over Whether It Limits Abortion Enough." New York Times, 19 March 2010.

81. David M. Herszenhorn, and Robert Pear. "Lawmakers Recess and Prepare to Defend Health Votes." New York Times, 26 March 2010.

82. See E.J. Dionne, Jr. “On Health Care, Listen to the Nuns.” Washington Post, 18 March 2010.

83. On final passage of the main bill and accompanying reconciliation measure, see David M. Herszenhorn, and Robert Pear. "Obama Hails Vote on Health Care as Answering 'the Call of History'." New York Times, 22 March 2010.

84. On the comparison between the House and final Senate bills, see the analysis by Washington \& Lee University School of Law Professor Timothy Stoltzfus Jost. "Response to the Bishops." Available online: http:/ /law.wlu.edu/faculty/facultydocuments/jost/Jost_Response_to_Bishops_3.14.10.pdf (accessed on 7 May 2012).

85. On the bishops' role in the final legislative end game, see Cardinal Francis George. "The USCCB and Health Care Reform." Available online: http://wwwmigrate.usccb.org/issues-and-action/human-life-anddignity/health-care/upload/health-care-reform-summary-2010.pdf (accessed on 14 March 2011).

86. Jerry Filteau. "Fact Checked: U.S. Bishops on Health Care Reform." National Catholic Reporter Online. Available online: http://ncronline.org/news/politics/fact-checked-us-bishops-health-care-reform (accessed on 14 March 2011). 
87. As with all things political, the dynamics here are complex. John Boehner eventually being forced out as Speaker of the House by Tea Party hardliners in late 2015 might suggest a similar view, but is much harder to tie to any specific dynamic associated with his Catholicism (despite the fact his decision occurred immediately after meeting Pope Francis). But Paul Ryan's and Nancy Pelosi's continuing high-profile roles complicate any such argument. See Carl Hulse. "Handing the Mike to a Departing John Boehner." New York Times, 29 October 2015.

88. The Christian personalism strand of Catholic theology, mediated most prominently into the tradition through the writings of Karol Wojtyla both before and after becoming Pope John Paul II, provide one important route through which the latter encounter is occurring. See Andrew N. Woznicki. A Christian Humanism: Karol Wojtyla's Existential Psersonalism. New Britain: Mariel Publications, 1980.

89. Patrick Grant. Personalism and the Politics of Culture: Readings in Literature and Religion from the New Testament to the Poetry of Northern Ireland. Basingstoke: Macmillan, 1996.

90. Philip Gleason. "The New Americanism in Catholic Historiography." U.S. Catholic Historian 11 (1993): 1-18.

91. For the foundational analyses of authority dynamics in society, see the following by Max Weber. "The Types of Legitimate Domination." In Economy and Society. Berkeley: University of California Press, 1968, pp. 212-54.

92. Max Weber. "The Distribution of Power within the Political Community: Class, Status, and Party." In Economy and Society. Berkeley: University of California Press, 1968, pp. 926-39.

93. Max Weber. "Bureaucracy." In Economy and Society. Berkeley: University of California Press, 1968, pp. $956-89$.

94. Martin E. Spencer. "Weber on Legitimate Norms and Authority." The British Journal of Sociology 21 (1970): 123-34. [CrossRef]

95. Georg Simmel. On Individuality and Social Forms. Edited by Donald N. Levine. Chicago: University of Chicago Press, 1971.

96. On the unencumbered self, see Michael J. Sandel. "The Procedural Republic and the Unencumbered Self." Political Theory 12 (1984): 81-96. [CrossRef]

97. On the distinction between authoritarian, authoritative, and permissive styles, see the pioneering work of Diana Baumrind. "Current patterns of parental authority." Developmental Psychology 4 (1971): 1-103. [CrossRef]

98. Eleanor E. Maccoby, and John A. Martin. "Socialization in the context of the family: Parent-child interaction." Handbook of Child Psychology, (1983): 1-101. Available online: https:/ /www.researchgate.net/publication/ 233821914_Socialization_In_The_Context_Of_The_Family_Parent-Child_Interaction (accessed on 1 Feburary 2016).

99. Susie D. Lamborn, Nina S. Mounts, Laurence Steinberg, and Sanford M Dornbusch. "Patterns of competence and adjustment among adolescents from authoritative, authoritarian, indulgent, and neglectful families." Child Development 62 (1991): 1049-65. [CrossRef] [PubMed]

100. For a much more sympathetic view of how the deification of the self has created a powerful dynamism within American culture, see Harold Bloom. The American Religion: The Emergence of the Post-Christian Nation, 2nd ed. New York: Chu Hartley Publishers, 2006. Obviously, I view this dynamic with far less enthusiasm than does Bloom.

101. A fine secular analysis of the possibilities and thin enactment of Catholic communitarianism can be found in Paul Lichterman. Elusive Togetherness: Church Groups Trying to Bridge America's Divisions. Princeton: Princeton University Press, 2005.

102. On the chaos and incoherence of contemporary Catholic culture, along with its potential, see Peter Steinfels. A People Adrift: The Crisis of the Roman Catholic Church in America. New York: Simon and Schuster, 2004.

103. A parallel public controversy was seen in the May 2009 debate regarding the University of Notre Dame's invitation to President Obama to speak on campus and receive an honorary degree, with the more sectarian Catholic voices arguing he should be excluded due to his support for abortion rights and embryonic stem cell research. Peter Baker, and Susan Saulny. "At Notre Dame, Obama Calls for Civil Tone in Abortion Debate." New York Times, 17 May 2009.

104. The text of Obama's speech at Notre Dame. Available online: www.nytimes.com/2009/05/17/us/politics/ 17text-obama.html (accessed on 14 March 2011).

105. On the Vatican's commentary regarding Obama, see for example E. J. Dionne, Jr. "The Stakes at Notre Dame." Washington Post, 7 May 2009. 
106. The original, classic formulation is found in Ernst Troeltsch. The Social Teaching of the Christian Churches. Translated by Olive Wyon. London: Allen \& Unwin, 1950. In America, "denominations" have come to supplant the full-blown Church and sect ideal types rooted in European history, but American Catholicism has adhered to a version of denominationalism close to the Church type.

107. On the tensions and sharp exchanges among the bishops in November 2015, see Michael Sean Winters' observations at "Reflection on the USCCB Meeting, Part I." Available online: http:/ /ncronline.org/blogs/ distinctly-catholic/reflections-usccb-meeting-part-i (accessed on 19 December 2015).

108. On the subsequent public debate, see Michael Sean Winters. "Reflection on the USCCB Meeting, Part II." Available online: http://ncronline.org/blogs/distinctly-catholic/opposition-pope-francis-comes-out-closet (accessed on 19 December 2015).

109. On Winters' view of "synodality" and its rootedness in Pope Francis' leadership, see "Distinctly Catholic." Available online: http://ncronline.org/blogs/distinctly-catholic/reflections-usccb-meeting-part-ii (accessed on 20 December 2015).

110. See Paul DiMaggio. "Culture and Cognition." Annual Review of Sociology 23 (1997): 263-87. [CrossRef]

111. For the sociological foundations of this insight, see Emile Durkheim. "The Dualism of Human Nature and Its Social Conditions." In Emile Durkheim on Morality and Society. Edited by Robert N. Bellah. Chicago: University of Chicago, 1973.

112. On the "sense of the faithful," see [20,21] as well as Paul G. Crowley. "The Sensus Fidelium and Catholicity: Newman's Legacy in the Age of Inculturation." In John Henry Newman. New York: Garland, 1992.

113. Daniel J. Finucane. Sensus Fidelium: The Use of a Concept in the Post-Vatican II Era. San Francisco: International Scholars Publications, 1996.

114. Richard John Neuhaus. The Catholic Moment: The Paradox of the Church in the Postmodern World. San Francisco and London: Harper \& Row, 1987.

(C) 2016 by the author; licensee MDPI, Basel, Switzerland. This article is an open access article distributed under the terms and conditions of the Creative Commons by Attribution (CC-BY) license (http://creativecommons.org/licenses/by/4.0/). 